\title{
Variation in timing of breeding of five woodpeckers in a primeval forest over 45 years: role of food, weather, and climate
}

\author{
Tomasz Wesołowski ${ }^{1}$ Grzegorz Hebda ${ }^{2} \cdot$ Patryk Rowiński $^{3}$
}

Received: 15 March 2020 / Revised: 15 August 2020 / Accepted: 30 August 2020 / Published online: 11 September 2020

(c) The Author(s) 2020

\begin{abstract}
Climate warming could lead to 'mis-matching' of birds' breeding times with availability of their invertebrate food resources. Fluctuating spring temperatures could influence variation in the commencement of egg-laying, as well as, in phenology of their resources (e.g., tree bud burst, appearance of folivorous caterpillars). We studied timing of Dendrocopos leucotos, Dendrocoptes medius, Dendrocopos major, Dryobates minor, and Picoides tridactylus breeding in, free of direct human intervention, strictly protected fragments of Białowieża Forest (Poland) in 1975-2019. We related their onset of breeding to inter-year variation in spring weather, trees' bud burst and timing of folivorous caterpillars' availability. Individual species initiated breeding at dates differing by a month. In spite of intraseasonal differences in the absolute laying dates, sometimes exceeding three weeks, the sequence of laying by different species within a season was highly repeatable; D. leucotos commenced the first and P. tridactylus the last. Within a species and season, the females commenced laying synchronously; usually $50 \%$ of them begun laying $\leq 8$ days of each other. All species bred earlier when spring temperatures got higher. Nestling time of $D$. medius and $D$. major broadly coincided with 'caterpillar peaks', while $D$. minor young appeared too late. All woodpeckers advanced egg-laying in Białowieża National Park over 45 years but the inter-specific sequence of laying has been retained. These could be responses to strong advance of snow disappearance and to warming of the second half of April. The early recent laying dates remained within the range of earlier recorded ones, the early springs just became more frequent. Thus, the phenological acclimatization could be achieved by plastic behavioural and physiological adjustments. Lack of data on types of food actually used and their seasonal variation hinders mechanistic understanding of how warming would affect the future food supply and breeding performance of birds.
\end{abstract}

Keywords Białowieża national park $\cdot$ Primeval forest $\cdot$ Caterpillar peak $\cdot$ Temporal food matching

Communicated by F. Bairlein.

Electronic supplementary material The online version of this article (https://doi.org/10.1007/s10336-020-01817-1) contains supplementary material, which is available to authorized users.

Tomasz Wesołowski

tomasz.wesolowski@uwr.edu.pl

1 Laboratory of Forest Biology, Wrocław University, Sienkiewicza 21, 50335 Wrocław, Poland

2 Institute of Biology, Opole University, Oleska 22, Opole, Poland

3 Department of Forest Zoology and Wildlife Management, Institute of Forest Sciences, Warsaw University of Life Sciences-SGGW, Nowoursynowska 159, 02776 Warszawa, Poland 


\section{Zusammenfassung}

\section{Variation der Brutzeiten von fünf Spechtarten in einem Urwald über 45 Jahre hinweg: die Rolle von Nahrung, Wetter und Klima}

Die Klimaerwärmung könnte bei Vögeln zu einer Fehlanpassung zwischen Brutzeit und Verfügbarkeit von Insekten als ihren Nahrungsressourcen führen. Temperaturschwankungen im Frühling könnten Veränderungen im Beginn der Eiablagen wie auch in der Phänologie ihrer Nahrungsressourcen bedingen (z.B. Ausbruch der Baumblüte, Auftreten blätterfressender Raupen). Wir untersuchten dieses Timing von 1975 bis 2019 bei im Freiland brütenden Weißrückenspechten (Dendrocopos leucotos), Mittelspechten (Dendrocoptes medius), Buntspechten (Dendrocopos major), Kleinspechten (Dryobates minor) und Dreizehenspechten (Picoides tridactylus) in streng geschützten Bereichen des Białowieża Waldes in Polen. Dabei setzten wir ihren jeweiligen Brutbeginn in Beziehung zu den unterschiedlichen Wetterbedingungen in den einzelnen Jahren und dem Ausbruch der Baumblüte und dem beginnenden Auftreten von blätterfressenden Raupen. Der Brutbeginn der einzelnen Spechtarten variierte um einen Monat. Trotz der intrasaisonalen Unterschiede in den Eiablagedaten, die manchmal mehr als drei Wochen betrugen, war die Reihenfolge der Eiablagen der verschiedenen Arten reproduzier- und vorhersagbar; D. leucotos lag immer auf dem ersten, P. tridactylus auf dem letzten Platz. Innerhalb einer Art und Saison war der Beginn der Eiablage bei den Weibchen synchron; normalerweise begannen 50\% von ihnen innerhalb von $\leq 8$ Tagen Abstand untereinander. Alle Arten brüteten früher, wenn die Frühlingstemperaturen stiegen. Die Zeit der Nestlinge fiel weitgehend in die Zeit mit den meisten Raupen, wobei die Jungen von D. minor zu spät zu kommen schienen. Alle Spechtarten in den 45 Jahren im Białowieża-Nationalpark begannen früher mit der Eiablage, aber die Reihenfolge der einzelnen Arten blieb immer die gleiche. Dies könnte eine Reaktion auf den starken Schneerückgang und die Erwärmung in der zweiten Aprilhälfte sein. Die neueren Eiablage-Daten lagen innerhalb der Spannbreite von früher aufgezeichneten, nur wurden die frühen Frühlinge immer häufiger. So könnte eine phänologische Anpassung mithilfe von flexiblen Feinanpassungen in Verhalten und Physiologie erreicht werden. Der Mangel an Daten über die tatsächlich verwertete Nahrung und deren jahreszeitlich unterschiedliche Verfügbarkeit erschwert das Verständnis dafür, wie sich die Klimaerwärmung auf die zukünftige Nahrungsversorgung und das Brutverhalten von Vögeln auswirken könnte.

\section{Introduction}

The timing of reproduction and synchronisation with varying environmental conditions constitutes a major problem for all organisms living in seasonal environments. Breeding should occur when the chances of producing offspring are highest (benign weather, low predation threat, abundant food, e.g., Immelmann 1971; Stutchbury and Morton 2001). Lack (1950) suggested that the variation in food resources was the most important factor and postulated that the breeding season of each species should be adapted, so that it coincided with the time of the year when there was abundant food for the young. For insectivorous birds in the North temperate and boreal forests, this period occurs generally in spring, when temperatures typically rise and invertebrates become more plentiful. The insectivorous birds (including woodpeckers, cf. reviews in Glutz von Blotzheim and Bauer 1994; Pasinelli 2003; Michalek and Miettinen 2003) breed at this time of year. However, there is much variation among species and across years. For example, European Nuthatches Sitta europaea (Wesołowski and Cholewa 2009) and Redbreasted Flycatchers Ficedula parva (Mitrus et al. 2005) commence egg laying almost 2 months apart in the same forest, while the same Marsh Tit females Poecile palustris can lay eggs almost three weeks apart in two consecutive springs (Wesołowski et al. 2016). Thus, to test the 'food for young' hypothesis, one needs to collect much more specific data on both the types of food actually brought to the young of the studied species, and the temporal variation in the availability of these food types (Cholewa and Wesołowski 2011).

Several authors have found that, contrary to expectations, a large fraction of females commenced breeding too late to rear young synchronously with peak availability of food for the young (Perrins 1965, 1970; Daan et al. 1988; Drent 2006). Perrins $(1965,1970)$ suggested that this was because the laying females were delayed due to their inability to obtain adequate food. This postulate was confirmed in several food supplementation experiments, including food provisioning of Dendrocopos major in the pre-breeding period (Smith and Smith 2013), where the extra-fed birds did advance egg-laying (meta-analysis of Ruffino et al. 2014). Therefore, 'food for females', the availability of food for egg-forming birds, could be more critical in shaping variation in breeding time than the synchronisation of the presence of young with the peak of their food availability. The birds should commence laying as early as they possibly can, as the survival and recruitment rates of the later fledged young are usually lower than early ones. Young which fledge late may survive less well because of, e.g., declining food availability (review in Daan et al. 1988), increased vulnerability to predation (Naef-Daenzer et al. 2001) or deteriorating weather conditions. There could be an additional social cost of delayed fledging - the necessity of competing, with the earlier-fledged young. In such a situation, the advantages 
of early breeding accrue from producing fledglings earlier than other birds in a local population and not from producing them early in absolute (calendar date) terms (Nilsson and Smith 1988, Wesołowski 2000).

In practice, it is difficult to differentiate between the 'food for females' and 'food for young' hypotheses. Rarely are the food resources available to the birds from egg laying to chick rearing known and quantified, additionally-in contemporary forests - the variation in prey availability can be substantially modified by human actions. The impacts could be indirect, e.g., changed timing of seasonal food peaks due to climate warming (see below), or via altered structure of forest landscapes (reviewed by Niemelä 1997; Wesołowski and Rowiński 2006). They could be also direct, e.g., by application of insecticides or other means of 'pest' control (reviewed by Dajoz 2000). However, it is still possible to study the effects of varying food availability in conditions nearing that of primeval forests in the Białowieża Forest (eastern Poland) (Tomiałojć et al. 1984; Tomiałojć and Wesołowski 2005; Wesołowski 2007). In this forest, food sources are diverse and are free of control by human management. Outbreaks of both folivorous caterpillars (Wesołowski and Rowiński 2006, 2008) and bark beetles (Ips typographus, Gutowski and Jaroszewicz 2016) occur regularly. The impact of such resource pulses, though, is buffered by the diverse array of other food types available to birds (Rowiński 2001; Maziarz and Wesołowski 2010).

Spring temperatures are the most important factor influencing short-term variation in the commencement of egglaying by forest birds (e.g., Perrins 1973, 1991; Schmidt 1984; Visser et al. 2006; Wesołowski and Cholewa 2009), including woodpeckers (e.g. Ivanchev 1996; Wiktander et al. 2001; Hebda and Szewczyk 2005). They also affect the underlying processes such as the timing of bud burst on trees (review in Chmielewski and Rötzer 2001; Wesołowski and Rowiński 2006) and appearance of folivorous caterpillars (e.g., van Dongen et al. 1997; Visser et al. 1998). However, the importance of the variation in spring temperatures has been recently overshadowed by concerns about possible effects of long-term climate warming (IPCC 2014) on birds' phenology and desynchronisation ('mis-matching') of their breeding cycles with other trophic levels (e.g., reviews in Bairlein and Winkel 2000; Pulido and Berthold 2004; Crick and Sparks 2006; Dunn and Winkler 2010, Burgess et al. 2018). These worries have stimulated disputes on possible coping mechanisms; whether the birds would be able to adjust to these novel challenges by means of behavioural and physiological plasticity or whether selection leading to microevolutionary changes would be necessary (Charmantier and Gienapp 2014; Wesołowski et al. 2016).

Spring temperatures in the Białowieża Forest, on which commencement of breeding by numerous passerines (Wesołowski and Cholewa 2009) and timing of tree-leaf development (Wesołowski and Rowiński 2006) depend, are highly variable from year to year (e.g., Wesołowski et al. 2016), yet they show only limited signs of change over long run. Only the second half of April has become significantly warmer there in the last decades of the twentieth century (Wesołowski and Cholewa 2009). This relative climatic stability, in addition to the reasons presented above, makes the Białowieża Forest, a valuable place to study relationships between weather, resources, and timing of birds breeding (Wesołowski and Neubauer 2017; Wesołowski et al. 2019).

Nine woodpecker species breed in the Białowieża Forest often close to one another in the same forest patches (Wesołowski et al. 2003; Tomiałojć and Wesołowski 2004). Preliminary data (Wesołowski and Tomiałojć 1986; Wesołowski 1995) showed that, despite the shared environments and considerable annual variation, individual species consistently tended to rear young at different times of the year. Having collected data on five of the woodpecker species living in this forest over 45 breeding seasons, in this paper, we explore the inter-specific and inter-year variation in their breeding time in more detail. We check whether, within a year, individual species commenced breeding at different times and whether the order of breeding initiation was consistent among years. We also look for likely impacts of climate warming by checking if the laying dates of individual species showed any long-term advancing trends. We further examine how the onset of breeding of individual species was related to inter-year variation in spring weather conditions (expecting the birds breeding earlier in warmer springs), the development of leaves on trees, and the timing of folivorous caterpillars' (i.e., the potential food source of several species) appearance (anticipating to find some match between the caterpillars' supply and nestlings' requirements). Finally, combining our data with information from literature, we attempt to explain the proximate and ultimate (adaptive) drivers of the timing of woodpecker breeding. We also try to make some predictions on possible effects of continuing climate warming on their breeding phenology.

\section{Methods}

\section{Study area}

The Białowieża Forest complex is situated in the middle of the European plain, at the Polish-Belarusian border (co-ordinates of Białowieża village: $52^{\circ} 41^{\prime} \mathrm{N}$ and $23^{\circ} 52^{\prime}$ E). The western part of the forest $\left(613 \mathrm{~km}^{2}\right.$, ca $45 \%$ of the area) is situated in Poland. The forest represents a remnant of the vast lowland forests that once covered large parts of temperate Europe. Its considerable size and an exceptionally good state of preservation (Tomiałojć and Wesołowski 1990; Wesołowski 2005, 2007) make the forest unique. The 
majority of the tree stands in the Polish part are now under management, but a $47.5 \mathrm{~km}^{2}$ block of the best preserved primeval old-growth stands has been retained within the strictly protected part of Białowieża National Park (NP hereafter).

Searches for woodpecker nest holes were undertaken mainly during census work carried out in permanent study plots situated within the strictly protected part of Białowieża NP during the 1975-2019 breeding seasons (Wesołowski and Tomiałojć 1986; Tomiałojć and Wesołowski 1990; Wesołowski et al. 2015). The total area censused covered 358 ha in the 1970s (Tomiałojć et al. 1984) and 187.5 ha in the following seasons. The plots studied were situated in the three main types of mature forest stands described below. The share of individual habitats within the plots reflected their share in Białowieża NP.

These primeval stands are multi-storey, mixed-species, and uneven-aged with a canopy formed by trees over 200 (up to 400) years (Tomiałojć and Wesołowski 2004). They contain many tall (up to $50 \mathrm{~m}$ ) and thick (breast height diameter $>235 \mathrm{~cm}$ ) veteran trees (Niechoda and Korbel 2011). They also contain large amounts of standing dead and fallen trees (20-25\% of total wood volume, Bobiec 2002). Details of these study plots are given in Wesołowski et al. (2015) and Tomiałojć and Wesołowski (1990, 2005).

Lime-hornbeam stands (Tilio-Carpinetum, c. $44 \%$ of Białowieża NP) are structurally the most diverse with a dozen or so species of trees (i.e., hornbeam Carpinus betulus, lime Tilia cordata, pedunculate oak Quercus robur, Norway spruce Picea abies, Norway maple Acer platanoides) that vary greatly in age and size. Swampy deciduous stands (Ribeso nigri-Alnetum, Fraxino-Alnetum, c. $22 \%$ of Białowieża NP area) are more uniform, with a canopy composed mostly of alder Alnus glutinosa, ash Fraxinus excelsior, and spruce. This habitat type is characterized by the highest amount of dead wood; there are about three times more fallen logs here than in the lime-hornbeam stands. In the coniferous stands (Peucedano-Pinetum, c. $28 \%$ of Białowieża NP area), the canopy is composed of spruce and Scots pine Pinus sylvestris with an admixture of birches Betula spp. and some oaks.

\section{Field observations}

Observations were carried out in 1975-2019 (45 breeding seasons). They usually started at the beginning of April and lasted until the end of June. During repeated visits to the census plots, all signs of woodpecker breeding activity were recorded (i.e., hole excavation, copulation, collecting food for young and calls of nestlings) and the breeding holes were located (Wesołowski and Tomiałojć 1986). Details of woodpecker behaviour at holes (bird entered hole, fed from the entrance, head of young in the entrance) were collected as well. Additionally, any nests outside the core study plots, in structurally similar areas in other parts of Białowieża NP, were recorded. Depending on species such holes constituted $13-45 \%$ of all recorded. Most holes (66-80\% depending on species) were found at the nestling stage.

We gathered observations on leaf development in the lime-hornbeam plot in 1997-2019 (23 years). Every 2 days, the leaf development stage of four most numerous deciduous tree species (hornbeam, lime, pedunculate oak, Norway maple) was recorded. Observations continued until shoots on all sample trees had developed small unfolded leaves. Details of the field procedures are described in Wesołowski and Rowiński (2006, 2008, 2014).

To collect data on the seasonal pattern of the biomass of folivorous caterpillars, and to detect seasonal peaks in their availability, caterpillar frass was collected in 1998-2019 (22 years). Frass collectors were placed under tree crowns in two lime-hornbeam plots. In each plot, ten groups of trees, each consisting of one pedunculate oak, one Norway maple, one hornbeam, and one lime, were used. The frass collectors were emptied every 2 (three in 1998) days from the bud burst till early June when the mass of falling frass became too small to be reliably measured. Field methods are fully described in Wesołowski and Rowiński (2008, 2014), Maziarz and Wesołowski (2010), and Wesołowski et al. (2019).

\section{Data analysis}

Nine woodpecker species breed in Białowieża NP (Wesołowski et al. 2003; Tomiałojć and Wesołowski 2004), but, here, we deal with only five resident species for which we have enough information on breeding attempts: Whitebacked Woodpecker (Dendrocopos leucotos, WB), Middle Spotted Woodpecker (Dendrocoptes medius, MS), Great Spotted Woodpecker (Dendrocopos major, GS), Lesser Spotted Woodpecker (Dryobates minor, LS), and Threetoed Woodpecker (Picoides tridactylus, TT). To make the text more concise, we use these acronyms of their names in the rest of this paper.

The overwhelming majority of the data used in this paper have been never published. However, to extend the length of the time series covered, we included some information recalculated from the fledging dates presented in Wesołowski and Tomiałojć (1986; five species, years 1975-1983) and Wesołowski (1995; WB, years 1975--1994).

We assessed the first egg dates by back calculation from all the information available in the field notes. After assessing the stage of nesting cycle from the information given (Cisakowski 1992, Electronic Supplementary Material Table S1 and Table S2), we subtracted-as appropriatethe estimated age of young, length of the incubation period, and clutch size (one egg a day) from the observation date. The lengths of these periods used in different species are shown in Electronic Supplementary Material Table S1. As 
numerous nest records consisted of only single observations, it was usually only feasible to establish a range of possible first egg dates, e.g., TT nestlings protruding heads from the hole's entrance could be 16-23 days old; therefore, the first egg in this nest could be laid 33-38 days before the observation day. We were able to estimate the first egg date to within a range of 0-7 days for most nests [71\% (GS) to 81\% (TT)]. For each brood we calculated the mid-range-date and used this value in all the analyses. The number of dates available for species and seasons varied from nil to 79 (Supplementary Material Table S3).

To compare laying dates across species and years, we used the earliest laying dates for each species and each year. This was because the calculation of meaningful central values was not possible for the less numerous species in some years due to small number of broods found. The usage of the extreme dates was adequate to describe year-to-year variation in the breeding seasons, though, as they were very tightly correlated with the median values (calculated only for springs with $\geq 5$ cases/species) of the respective years. The $r_{\mathrm{s}}$ values were 0.87 ( $n=43$ years) in GS, $0.86(n=34)$ in MS and 0.91 ( $n=12$ years) in WB; $P<0.001$ in each case.

To check whether presence of Starlings Sturnus vulgaris delayed nesting of the woodpeckers, we compared the woodpecker laying dates in areas without (most of the forest area) and with breeding Starlings. These birds bred in high densities (exceeding 20 pairs/10 ha in some years) only in two plots bordering the forest edge (plots $K$ and $W$, Wesołowski et al. 2015).

To analyse relationships between meteorological variables and the woodpecker breeding dates, we used data gathered by a local weather station localised in nearby Białowieża village. We used mean daily temperatures $\left({ }^{\circ} \mathrm{C}\right)$ averaged over each half-month period beginning from March 1. This is because the Białowieża region has a continental climate, and relatively harsh winter conditions (subzero temperatures, snow cover) prevail in January and February. Hence, it seems that the beginning of March could be the earliest date at which the rising temperatures could affect the birds' commencement of breeding (Wesołowski and Cholewa 2009). Following earlier approach (Wesołowski and Cholewa 2009), we used temperatures scored from different starting dates and correlated the mean temperatures of these periods with the mean egg-laying dates of individual species. For each year, we calculated mean temperatures of the first and second half of March and April, mean temperatures of consecutive one and a half month's periods within this range as well as mean temperatures of March and April. We compared all these means with the dates of onset of egg laying of individual species. We used in the final analyses the periods that produced the highest correlation coefficients with commencement of laying by individual woodpecker species. These were mean March temperature in WB $\left(r_{\mathrm{s}}=-0.54, n=37\right)$, and mean midMarch-April temperature in other species $\left(r_{\mathrm{s}}=-0.46\right.$ to $-0.64, n=37-45$ years).

The retreat of snow could have an additive effect to increasing air temperatures. The melting of the snow brings a qualitative change to the environment as it opens forest floor, large fragments of tree trunks and limbs to make them accessible for foraging woodpeckers (e.g., WB switched to forage on decomposing fallen logs then, Czeszczewik 2009). As there are no leaves on trees, these newly emerged surfaces are exposed to full sun radiation, so they probably warm above level allowed by air temperatures alone. This, in turn, could stimulate invertebrate activity making the prey more accessible to foraging woodpeckers. Therefore, we included also dates of snow cover disappearance in the analyses. They were defined as the first day in a season in which snow cover measured at the weather station was $<1 \mathrm{~cm}$ deep.

To analyse relationships between appearance of leaves and emergence of folivorous caterpillars and the woodpeckers' breeding dates, we used the dates of full bud burst of hornbeam (i.e., the day on which index of its leaf development attained value of 100, Wesołowski and Rowiński 2006). We took this date as the moment of caterpillar appearance, because hornbeam provided c. $50 \%$ of leaves for folivorous caterpillars, and other trees (maples, early oaks) started to develop leaves at approximately the same time (Rowiński 2001; Wesołowski and Rowiński 2006, 2008).

Following Wesołowski and Rowiński (2008) and Maziarz and Wesołowski (2010), we determined the date of peak caterpillar abundance (caterpillar 'peak') as the day on which the mass of caterpillar frass reached its seasonal maximum. When high frass values lasted for several days, we treated mid-date of such plateaus as the 'peak' day (graphs showing the seasonal patterns of frass fall in the individual seasons are available in Maziarz and Wesołowski 2010; Wesołowski and Rowiński 2014; Wesołowski and Neubauer 2017; Wesołowski et al. 2019). We took the number of days between full bud burst of hornbeams and the 'peak' as a measure of caterpillars' rate of development.

\section{Statistical analysis}

The majority of the analyses used non-parametric tests (Kruskal-Wallis ANOVA, Spearman's correlation, Kendall Coefficient of Concordance). To express rates of change of breeding dates with time and temperatures, we used Multiple Linear Regression analysis. The established significance level in the statistical analysis was $P<0.05$. All probability values shown are two-tailed. All statistical analyses followed formulae in STATISTICA 12.0 (StatSoft 2014). 


\section{Results}

Over the years of the study and for all the species, woodpeckers commenced egg-laying in Białowieża NP over a period of almost 2.5 months; from March 24 (WB in 1990) to June 4 (GS in 2006). The individual species, however, commenced laying within more restricted periods, ranging from 33 (LS, $n=118$ ) to 53 days (GS, $n=982$ ) over 45 years. The species differed consistently in timing of their breeding (Fig. 1, Kruskal-Wallis ANOVA: $\left.H_{4,1784}=577.16 ; P \ll 0.001\right)$. WB was the earliest breeding species initiating laying mostly in the first decade of April (median-April 7). It was followed by GS and MS; these species commenced laying mostly in the third decade of April (medians-April 29-30). LS and TT initiated breeding mainly in the first decade of May (median-May 6 and May 9, respectively). The latest breeding TT commenced laying c. 30 days later than the earliest breeding WB.

Egg laying in different habitats occurred as a rule on similar dates (Table 1). Only MS laid eggs c. 2 days later in the riverine forest, and GS c. 3 days later in the coniferous than in the deciduous forests. Breeding within areas occupied by Starlings did not lead to delays in the onset of laying of GS, or MS there (K-W ANOVA: $H_{1,982}=0.13$, $P=0.722$ and $H_{1,415}=2.26, P=0.13$, respectively). However, WB commenced laying 3-4 days later in such areas (median values, $H_{1,175}=6.81, P=0.009$ ).

The median laying dates (yearly medians, only seasons with $\geq 5$ cases/species) had ranges of 20,18, and 14 days, respectively, for GS $(n=43)$, WB $(n=12)$, and MS $(n=34$ springs) (K-W ANOVA: $\left.H_{2,89}=17.74 ; P<0.001\right)$. For each of these species, egg laying in the middle $50 \%$ of clutches was well synchronized, with the middle half of females commencing laying within $\leq 8$ days in $67 \%$ (WB), $85 \%$ (MS), and $86 \%$ (GS) of seasons (Fig. 2; K-W ANOVA: $H_{2,89}=2.62 ; P=0.27$ ).

MS, GS, and WB showed substantial inter-year variation in the dates of laying commencement (Fig. 2). Differences between the median laying dates of their earliest and latest seasons amounted to 14, 21, and 24 days, respectively. Differences between the two most divergent consecutive years amounted to 14 days in WB, 11 days in MS, and 10 days in GS. Ranges of laying dates of the middle $50 \%$ of females (25-75\% percentiles, Fig. 2) did not overlap between such years (Fig. 2, K-W ANOVA, $P \gg 0.001$ in each species). TT (K-W ANOVA: $H_{36,94}=15.48$, $P=0.027)$ and LS (K-W ANOVA: $H_{41,118}=74.08$, $P=0.001)$ also showed significant inter-year variation in the egg-laying dates.

Despite large intraseasonal differences in the absolute laying dates (Fig. 2), the order of laying commencement by different species was highly repeatable across years
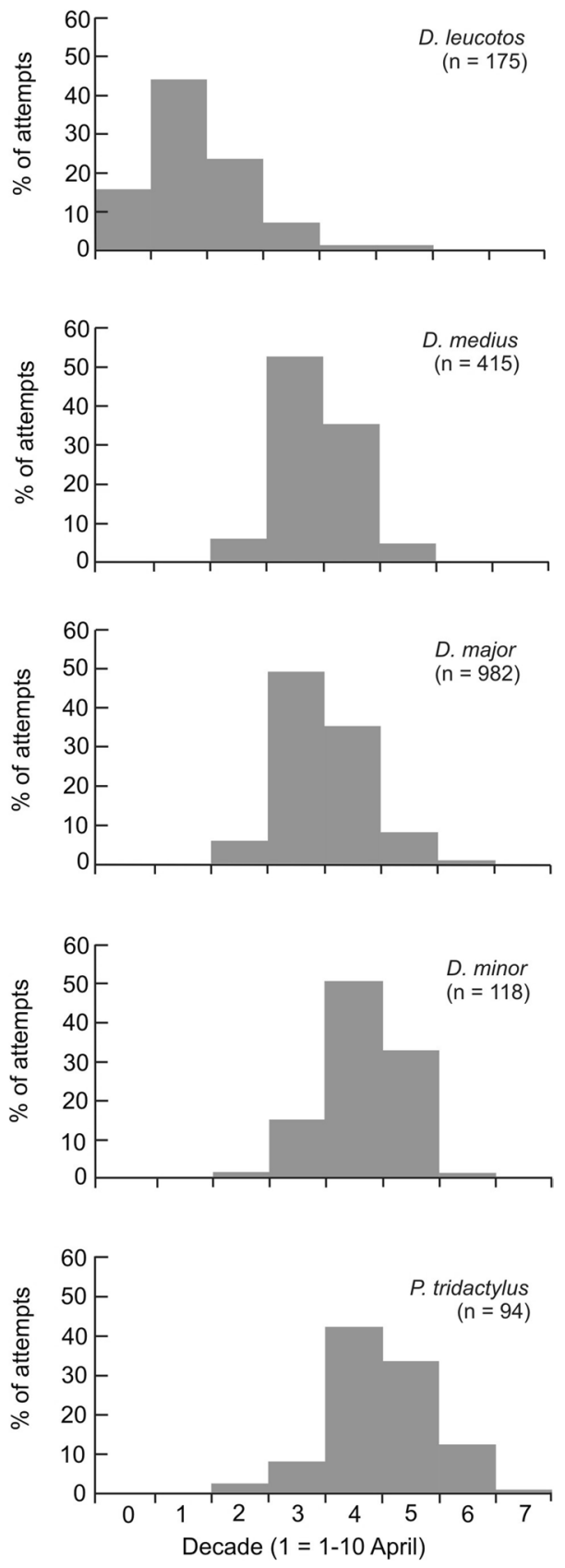

Fig. 1 Frequency distribution of dates of egg-laying commencement by the woodpeckers in the Białowieża NP. Pooled observations from all seasons (1975-2019, 45 years). WB $(n=175)$, MS $(n=415)$, GS $(n=982), \mathrm{LS}(n=118)$, and TT $(n=94)$

with WB laying first and TT last. The sequence of onset of egg laying in the earliest clutches of individual species was, in 30 years for which data on all the species were available, highly consistent (Kendall Coeff. of Concordance $\left.=0.87, \mathrm{chi}^{2}=104.09, P<<0.001\right)$.

All the species advanced egg-laying over 45 years but not at the same rates (Fig. 3). Egg laying accelerated most slowly in the earliest breeding WB ( -0.2 days/year, 9 days overall) 
Table 1 Distribution of dates of egg-laying commencement (1= April 1$)$ by five woodpecker species in Białowieża NP in 1975-2019 (45 years), in relation to habitat

\begin{tabular}{llrrrrr}
\hline Species & Habitat & $n$ & Median & Q25-75 & \multicolumn{2}{c}{ K-W ANOVA } \\
\cline { 5 - 7 } & & & & & & \multicolumn{1}{l}{ H } \\
\hline White-backed Woodpecker & Riverine & 74 & 7.8 & $1.5-13.5$ & & \\
Dendrocopos leucotos (WB) & Lime-hornb & 97 & 7.5 & $3.0-12.5$ & 0.39 & 0.822 \\
Middle Spotted Woodpecker & Riverine & 93 & 30.0 & $25.5-36.0$ & & \\
Dendrocoptes medius (MS) & Lime-hornb & 315 & 28.5 & $24.5-32.5$ & 9.5 & 0.009 \\
Great Spotted Woodpecker & Riverine & 228 & 29.5 & $25.0-34.0$ & & \\
Dendrocopos major $(\mathrm{GS})$ & Lime-hornb & 598 & 29.0 & $25.0-34.0$ & & \\
& Coniferous & 106 & 32.5 & $27.0-36.0$ & 15.0 & 0.001 \\
Lesser Spotted Woodpecker & Riverine & 42 & 38.3 & $33.0-43.0$ & & \\
Dryobates minor (LS) & Lime-hornb & 74 & 36.0 & $32.0-40.5$ & 2.7 & 0.103 \\
Three-toed Woodpecker & Riverine & 24 & 39.5 & $36.0-45.3$ & & \\
Picoides tridactylus (TT) & Lime-hornb & 33 & 38.5 & $34.5-44.0$ & & \\
& Coniferous & 35 & 43.0 & $36.5-49.5$ & 1.9 & 0.390 \\
\hline
\end{tabular}

and most rapidly in the latest commencing TT ( -0.4 days/ year, 19 days in total). The three other species were earlier by $10-13$ days (Fig. 3 ). As the minimum and median laying dates of the same seasons were very tightly correlated (cf. Figure 2 and 3, $r_{\mathrm{s}}=0.86-91, P<<0.001$ ), the medians followed this accelerating pattern as well (Fig. 2). However, despite these phenological trends, the dates of onset of laying observed near the end of the study remained within the range of dates recorded earlier for all the species studied. In recent years, extremely early seasons have become more frequent (Fig. 3).

The difference between the onset of laying of different species diminished over time; TT started to begin c. 37 days after WB in 1975-1984 but only c. 28 days following it in 2014-2019. Yet, despite this convergence of the breeding dates, the order of laying commencement by individual species remained unchanged.

The advance in timing of woodpecker breeding in Białowieża NP followed the strong local trend for snow cover to disappear earlier with time (Fig. 4). Snow melted around mid-April in 1975-1984, but it had often vanished by February in the last decade (Fig. 4), a 40-day shift. In many of the initial years of the study, woodpeckers initiated egg laying, while snow was still laying on the ground. For instance, in 7 years, when snow cover lasted till April 9-17, WB initiated laying up to 14 days before its disappearance. In the extremely late spring of 1984 (snow melted on April 28), GS and MS initiated laying c. 4 days before snow melt. All woodpeckers except WB advanced breeding in the springs in which snow disappeared earlier $\left(r_{\mathrm{s}}=0.39-0.46\right.$, $P<0.03$ in each case). However, the woodpecker breeding dates did not advance in proportion to the shifts in snow melt dates. The sooner the snow melted, the longer was interval between its disappearance and the birds' laying commencement $\left(r_{\mathrm{s}}=-0.84-0.95, P<0.001\right.$ in each case). In the extremely warm year of 2016 , when the snow had thawed
Fig. 2 Distribution of egg-laying commencement by woodpeckers in the Białowieża NP in relation to year. Shown are medians (squares) and $25-75 \%$ percentiles (boxes) for the years in which $\geq 5$ clutches were recorded 
Fig. 3 Long-term trends in the onset of laying (the earliest dates) by five woodpecker species in Białowieża NP, in the years 1975-2019. The linear regressions (solid lines), their 95\% Confidence Intervals (broken lines), regression slopes (B), and their probabilities are shown as well. The coefficients represent changes of laying dates per year
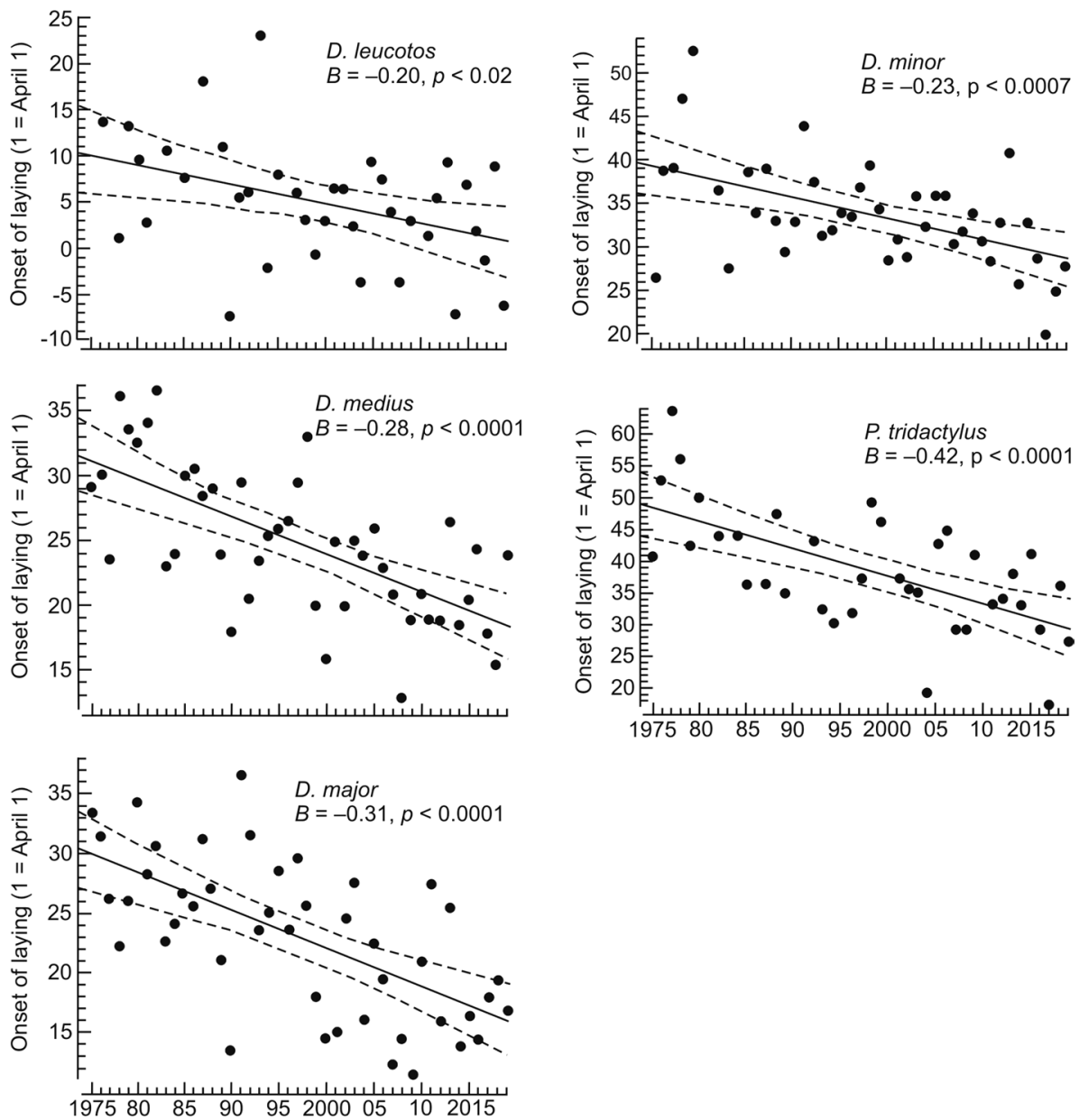

already on January 28, the birds began laying 64 (WB) to 91 (LS, TT) days after its disappearance.

Daily temperatures in the periods preceding breeding of the woodpeckers in Białowieża NP varied strongly across 45 years, but usually without no long-term trend to warming. Mean temperatures of half-month intervals in February-April did not consistently increased over time (Electronic Supplementary Material Table S4). Only the second half of April tended to warm up (Fig. 4). This increase was not uniform, though. The mean temperatures were increasing up to $2000(B=0.21, P=0.006)$, but no further rise occurred thereafter $(B=-0.06, P=0.528)$.

All the species commenced breeding earlier in warmer springs (Fig. 5), a one degree increase of mean daily temperatures was matched by $2-3$ days' earlier commencement of egg laying (Table 2). The temperatures explained most of the variation in the egg-laying commencement (Table 2), but in the case of MS and GS median laying dates, the dates of snow melt contributed significantly, as well (Table 2).

The development of leaves on trees in Białowieża NP, expressed as a date of burst of hornbeam buds occurred on April 14-May 5 (median April 25) in 1997-2019 (23 years). WB always commenced laying well ahead of bud burst (median $=-21$ days, Fig. 6). MS and GS started egg laying usually few (median 4-5) days before the bud burst, at that time first buds were already opened, while LS and TT commenced egg laying after (median $=9-11$ days) the burst, when leaves were already partially grown (Fig. 6). Across years, the egg-laying commencement in GS, MS, and LS was positively correlated with the bud burst dates $\left(r_{\mathrm{s}}=0.59-0.60, P<0.004\right)$. In the springs with the late development leaves (bud burst at the end of April), all the species but TT initiated laying before the buds opened.

Folivorous caterpillars, hatched at bud burst, stayed in tree crowns for a variable amount of time. In 1998-2019 (22 springs), it took 20-41 days from the hatch to seasonal peak of their availability. The peak occurred between May 11 and 29, with median of May 21. By the time of the caterpillar peak young from the earliest laid WB clutches were already mostly fledged (median age $=34$ days, Fig. 7) and nestlings from earliest laid GS and MS clutches were halfgrown (12-13 days, Fig. 7), but nestlings from clutches laid around the seasonal median dates were only 3 (GS) or 7 (MS) days old then. The clutches of LS and TT were only about to hatch (median -1 day, Fig. 7) when the caterpillars were at their peak. Thus, periods of nestling rearing in all 


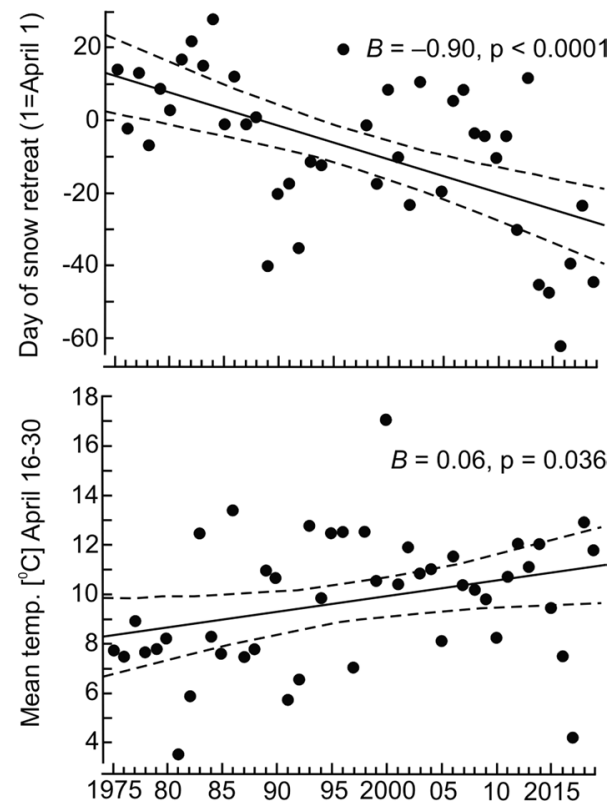

Fig. 4 Long-term trends in dates of snow disappearance (snow cover was $<1 \mathrm{~cm}$ deep, top) and in mean daily temperatures in the second half of April (bottom) in Białowieża NP in 1975-2019. The linear regressions (solid lines), their 95\% confidence intervals (broken lines), regression slopes (B), and their probabilities are shown as well. The coefficients represent the number of days (top) or the number of ${ }^{0} \mathrm{C}$ degrees (bottom) change per year

species but WB overlapped with the presence of the caterpillars in tree crowns, although the caterpillars were largely in their declining phase.

\section{Discussion}

\section{Order of breeding}

Despite sharing the same forest patches and having to cope with identical fluctuations in environmental conditions, the five woodpeckers studied in Białowieża NP initiated breeding at vastly divergent dates with their egg-laying times differed by a month (Fig. 1). Similar local spread of breeding dates was observed in North America (Drake and Martin 2018). Hairy Woodpecker Picoides villosus, the earliest of four woodpeckers breeding in British Columbia, Canada, initiated laying almost four weeks ahead of the latest breeding Downy Woodpecker Picoides pubescens.

The woodpeckers commenced laying in Białowieża NP in a strictly sequential fashion. Despite large, in some cases exceeding 3 weeks, interseasonal differences in the absolute laying dates, the order of laying commencement by different species within a season was highly repeatable. WB was usually the first, followed by (breeding at the same time) GS and MS. They were followed in turn by LS and TT. The place of a species in this sequence was not related to their body sizes or clutch sizes (Glutz von Blotzheim and Bauer 1994; Pasinelli 2003; Michalek and Miettinen 2003). It was also apparently not explained by variation in food types utilized (see below).

This fixed sequence of laying initiation found in Białowieża NP appears to be much more widespread. The same ranking of species phenologies was observed in other areas, as well (Table 3). Everywhere, from Switzerland and Norway, through Poland, Russia, up to Japan, WB bred c. 3 weeks earlier than the other species (Table 3 ). This phenomenon was observed in Poland as early as the nineteenth century (Table 3). Similarly, LS initiated breeding 4-7 days later than GS both in England, Poland, and Central Russia, while TT was the latest breeding species in the Alps and in Poland (Table 3). Thus, there exists a previously unrecognised but robust pattern; the inter-specific laying sequence of these woodpeckers is retained over thousands of kilometres, across vastly different forest types, under contrasting climatic conditions. The mechanisms keeping this pattern in place remain completely unknown.

\section{Proximate mechanisms and year-to-year variation}

Woodpeckers in Białowieża NP have shifted their breeding dates by 2-3 weeks in the 45 years (Fig. 3). Below we discuss possible sources of environmental information which could be used by woodpeckers in deciding when to breed. However, we wish to stress that whatever these outside inputs were, it seems that they were perceived and "interpreted" the same way by the majority of birds of each species. Within a season, the birds bred highly synchronously. Fifty percent of females in a population (25-75\% percentiles, Fig. 2) commenced laying within 8 days of each other in Białowieża NP, in $67-87 \%$ of springs. The same pattern has been observed in other areas (Table 4). Such uniformity of reactions across widely distributed populations suggests that the perception and assessment mechanisms allowing the birds to fine-tune their breeding time constitute adaptations, and that they have been selected for (Charmantier and Gienapp 2014; Wesołowski et al. 2016).

These short-term phenological shifts could be accomplished by phenotypic plasticity, flexible behavioural, and physiological responses of birds to varying weather conditions. To demonstrate unequivocally that it was really due to plasticity, one would have to compare the performance of the same individuals in contrasting environmental conditions (Charmantier and Gienapp 2014; Wesołowski et al. 2016). This was done for a North American Red-cockaded Woodpeckers (Picoides borealis, Schiegg et al. 2002), but it seems that there are apparently no studies of European species addressing this issue. 
Fig. 5 Relationship between spring temperatures and the earliest (filled dots) and median (empty triangles) laying dates of five woodpecker species, in Białowieża NP, in 1975-2019 (45 years). The linear regressions of the earliest (solid) and the median clutches (broken) lines are shown as well. Mean temperatures were calculated over the periods that best predicted the egg-laying dates of individual species (March in WB, mid-March-April in other species). The seasonal medians (calculated for seasons with $\geq 5$ cases/species) are available only for three species with larger samples of nests (cf. Figure 2). The numbers of seasons included in each comparison, as well as, the regression slopes (B) and their probabilities are given in Table 2
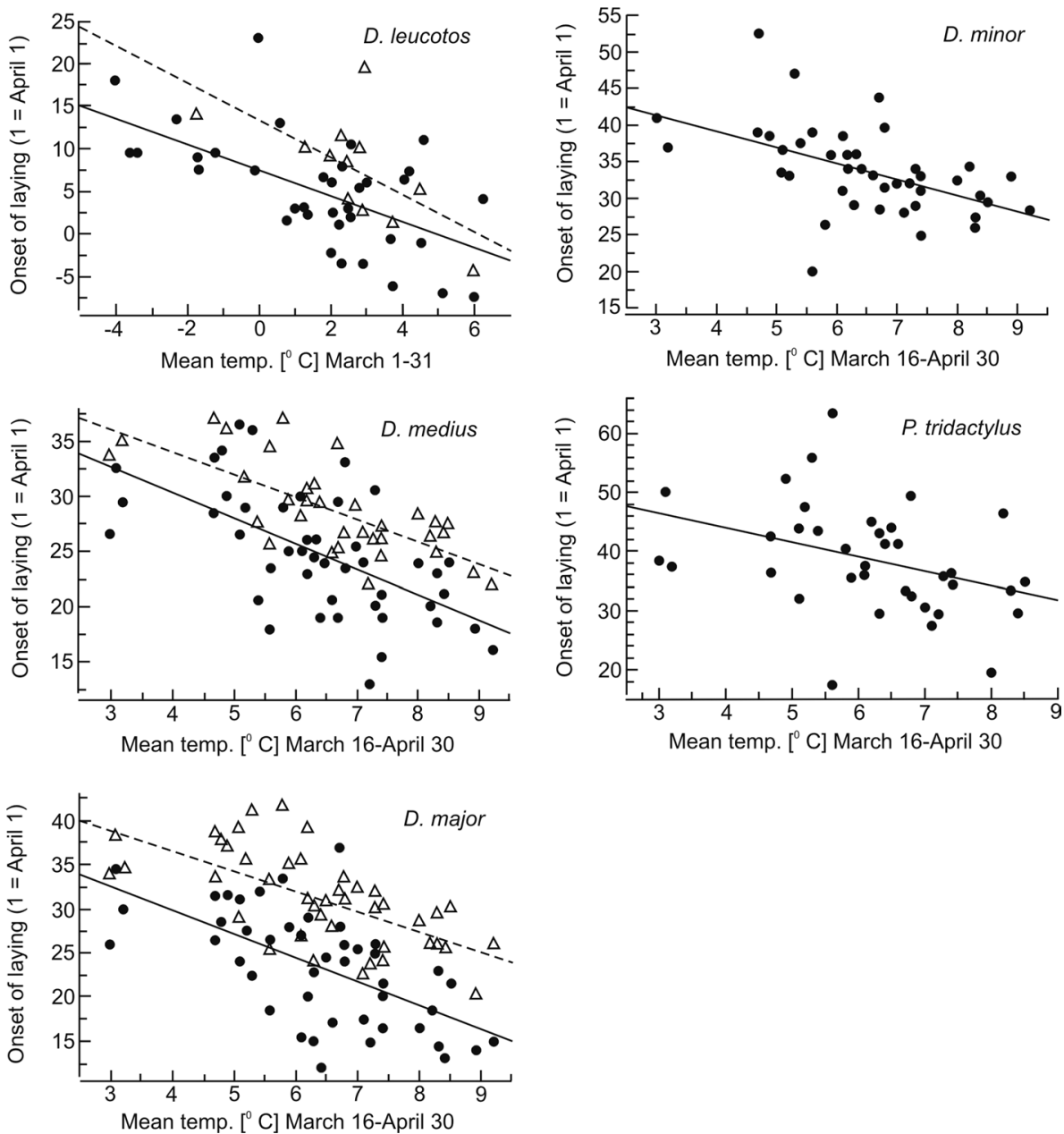

Table 2 Relationship between dates of snow disappearance, spring temperatures, and laying dates of five woodpecker species, in Białowieża NP, in 1975-2019

\begin{tabular}{|c|c|c|c|c|c|c|c|c|c|}
\hline \multirow[t]{3}{*}{ Species } & \multirow[t]{3}{*}{ Date } & \multirow[t]{3}{*}{ Yrs } & \multirow{2}{*}{\multicolumn{2}{|c|}{$\frac{\text { Spring temp }}{\text { Slope }}$}} & \multicolumn{5}{|c|}{ Multiple regression } \\
\hline & & & & & \multicolumn{2}{|c|}{ Snow melt } & \multicolumn{2}{|c|}{ Spring temp } & \multirow{2}{*}{$\begin{array}{l}\text { Overall } \\
p\end{array}$} \\
\hline & & & $B$ & $p$ & $b^{*}$ & $p$ & $b^{*}$ & $p$ & \\
\hline \multirow[t]{2}{*}{ Dendrocopos leucotos } & First & 37 & -1.5 & $<0.001$ & 0.02 & 0.921 & -0.60 & $<0.001$ & $<0.001$ \\
\hline & Median & 12 & -2.2 & 0.025 & 0.05 & 0.860 & -0.63 & 0.041 & 0.092 \\
\hline \multirow[t]{2}{*}{ Dendrocoptes medius } & First & 45 & -2.3 & $<0.001$ & 0.25 & 0.051 & -0.53 & $<0.001$ & $<0.001$ \\
\hline & Median & 34 & -2.0 & $<0.001$ & 0.26 & 0.035 & -0.65 & $<0.001$ & $<0.001$ \\
\hline \multirow[t]{2}{*}{ Dendrocopos major } & First & 45 & -2.7 & $<0.001$ & 0.23 & 0.073 & -0.55 & $<0.001$ & $<0.001$ \\
\hline & Median & 43 & -2.3 & $<0.001$ & 0.37 & 0.002 & -0.53 & $<0.001$ & $<0.001$ \\
\hline Dryobates minor & First & 42 & -2.1 & 0.001 & 0.24 & 0.095 & -0.44 & 0.003 & $<0.001$ \\
\hline Picoides tridactylus & First & 37 & -2.4 & 0.026 & 0.28 & 0.100 & -0.25 & 0.145 & 0.022 \\
\hline
\end{tabular}

Spring temperatures - mean of mean daily temperatures calculated over the periods that best predicted the egg-laying dates of individual species (March in WB, mid-March-April in other species, see Data Analysis). Regression coefficients $(B)$ represent changes in laying days $\left(\mathrm{d}^{0} \mathrm{C}^{-1}\right)$. Standardized regression coefficients $\left(b^{*}\right)$ indicate input of individual variables to the variation in breeding dates. Significant results bolded
The differences of median breeding dates between most disparate successive springs in Białowieża NP amounted to 10,11 , or 14 days for the GS, MS, and WB, respectively.
As numerous females bred probably in both years (they are highly site tenacious; reviews in Glutz von Blotzheim and Bauer 1994; Pasinelli 2003; Michalek and Miettinen 


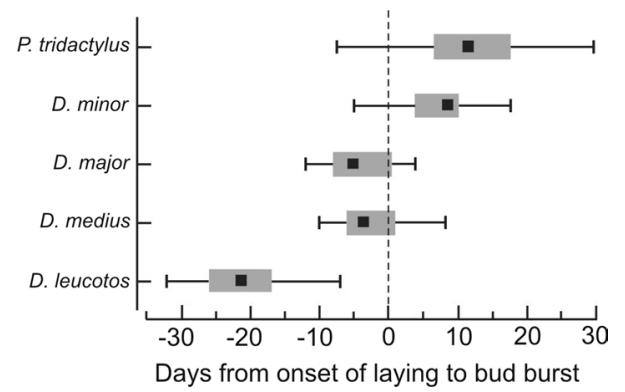

Fig. 6 Time interval ( $\mathrm{n}$ days) between hornbeam bud burst (=day 0) and the earliest laying dates of the five woodpeckers in Białowieża NP in different years (21-23 seasons/species) in 1997-2019. Medians (squares), 25-75\% (boxes), and minimum-maximum values (whiskers) of the earliest commenced broods are given

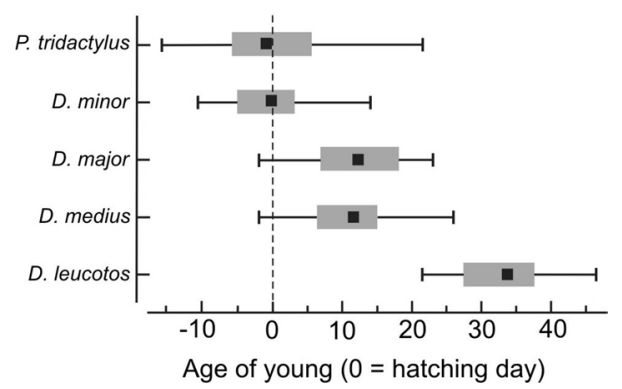

Fig. 7 Age of young $(0=$ hatching day) of the five woodpecker species in Białowieża NP at the seasonal peak of folivorous caterpillars availability in 1998-2019 (20-22 seasons/species). Medians (squares), 25-75\% (boxes) and minimum-maximum values (whiskers) of the earliest commenced broods are given
2003), it appears that the birds were able to shift their breeding dates by about 10-14 days, i.e., they could manage to breed in any type of spring (Fig. 5). Therefore, similarly to Marsh Tit (Wesołowski and Cholewa 2009; Wesołowski et al. 2016), the Białowieża breeding woodpeckers already possessed mechanisms allowing for immense plasticity of timing of egg-laying.

All woodpeckers in Białowieża NP were responsive to temperature breeding earlier when spring temperatures got higher (Fig. 5). This was also recorded in all other areas in which this relationship was checked (Table 4). Thus, it seems that the temperature dependence of the onset of breeding constitutes a universal biological mechanism in these species. Therefore, the woodpeckers follow a pattern prevailing in birds of temperate and boreal forests (review in Dunn and Winkler 2010).

Before discussing possible ways in which temperature variation could influence the timing of egg-laying, we first present another, potentially relevant, weather variable, namely date of snow cover disappearance. This factor is usually not even mentioned in the discussions of warming effects, but retreat of snow could have an effect additive to increasing air temperatures. Egg laying in MS and GS was, indeed, related to the retreat of snow, aside from spring temperatures (Table 2), but — contrary to expectation-the earliest breeding WB did not advance breeding in the springs in which snow disappeared earlier. However, the retreat of snow did not act as a trigger of reproduction; the sooner the snow melted the longer was interval between its disappearance and the birds' laying commencement. The presence of snow, on the other hand, could probably delay reproduction to some extent but not preventing the birds from initiation of breeding altogether. When snow stayed on the ground for

Table 3 Sequence of egg-laying initiation by sympatric woodpecker species in different areas

\begin{tabular}{llll}
\hline Laying order & Area & Years & Source \\
\hline WB-21-MS = GS-7-LS-4-TT & Białowieża NP, Poland & $1975-2019$ & This study \\
WB-GS-LS & E Poland & XIX cent., second half & Taczanowski (1882) \\
WB-20-GS-4-TT & Switzerland, Alps & $1967-1970$ & Ruge (1974) \\
WB-15-GS-9-TT the latest of all birds & S Germany, Bayerischer Wald & $1974-1977$ & Scherzinger (1982) \\
& & $1993-2004$ & Pechacek (2006) \\
WB-25-GS & Central Sweden & $1975-1982$ & Aulén (1988) \\
WB-14 d earlier than other woodpeckers & W Norway, 63 ${ }^{0}$ N & $1983-1994,10$ years, & Hogstad and Stenberg (2005) \\
WB-14-21-GS = MS & S Slovakia & $1995-1996$ & Pavlík (1999) \\
WB-19-GS-7-LS & Russia, SE from Moscow & $1984-1997$ & Ivanchev (1995, 1996, 2004) \\
WB-25-GS =Dendrocopos kizuki & Hokkaido/Honshiu, Japan & $1974-1976$ & Matsuoka (1979) \\
MS=GS & W Poland & $2003-2004$ & Kosiński and Ksit (2006) \\
GS-7-LS & England & $1939-1989$ & Glue and Boswell (1994) \\
LS later than other non-migratory birds & Sweden & $1989-1998$ & Wiktander et al. (2001) \\
LS later than other non-migratory passerines & SW Germany & $1996-2003$ & Rossmanith et al. (2007) \\
\hline
\end{tabular}

Species arranged from the earliest to the latest commencing egg-laying one. The numbers between the species names show an approximate difference ( $\mathrm{n}$ days) between the consecutive species. Full species names-see Table 1 
Table 4 Overview of information on synchrony of laying commencement within a season (span of laying dates, $\mathrm{n}$ of days), maximum shifts of laying dates among seasons ( $n$ days of difference between the minimum/median dates of the earliest and latest spring), and reports of the effects of increased spring temperatures on laying dates in five woodpecker species studied in Białowieża NP

\begin{tabular}{|c|c|c|c|c|c|c|}
\hline Species & Synchrony (d) & $\begin{array}{l}\text { Shift across } \\
\text { years }(d)\end{array}$ & $\begin{array}{l}\text { Earlier when } \\
\text { warm }\end{array}$ & $N$ years & Area & Source \\
\hline WB & 18 & 24 & Yes & 37 & Białowieża NP, Poland & This study \\
\hline WB & N/A & c. 30 & Yes & 8 & Russia, SE from Moscow & Ivanchev (1996) \\
\hline MS & 10 & 14 & Yes & 5 & SW Russia, Desna Polesie & $\begin{array}{l}\text { Kossenko and Kaygorodova } \\
(2003,2007)\end{array}$ \\
\hline MS & c. 9 & 7 & Yes & 4 & Switzerland & Pasinelli (2001) \\
\hline MS & 14 & 14 & Yes & 45 & Białowieża NP, Poland & This study \\
\hline GS & & & Yes & 22 & S England & Smith (2006) \\
\hline GS & 18 & c. 15 & N/A & 9 & S England & Smith and Smith (2019) \\
\hline GS & N/A & N/A & Yes & 3 & Warsaw, Poland & Mazgajski (2002b) \\
\hline GS & N/A & 19 & N/A & N/A & Poland & Hebda and Szewczyk (2005) \\
\hline GS & 20 & 21 & Yes & 45 & Białowieża NP, Poland & This study \\
\hline GS & c. 15 & 15 & Yes & 12 & Russia, SE from Moscow & Ivanchev (2004) \\
\hline LS & c. 12 & 17 & N/A & 10 & S Sweden & Wiktander et al. (2001) \\
\hline LS & N/A & 7 & N/A & 6 & SW Germany & Rossmanith et al. (2007) \\
\hline LS & N/A & 13 & Yes & 42 & Białowieża NP, Poland & This study \\
\hline LS & c. 10 & c. 13 & Yes & 7 & Russia, SE from Moscow & Ivanchev (1996) \\
\hline $\mathrm{TT}$ & c. 10 & 13 & N/A & 12 & S Germany & Pechacek and Krištín (2004) \\
\hline $\mathrm{TT}$ & N/A & 14 & Yes & 4 & Eastern Finland & Fayt (2006) \\
\hline $\mathrm{TT}$ & N/A & 46 & Yes & 37 & Białowieża NP, Poland & This study \\
\hline
\end{tabular}

N/A —information not available. Full species names—see Table 1

very long time (till the second half of April), WB initiated laying before snow had melted, and in the extremely late spring of 1984 (snow disappeared only on April 28), also GS and MS initiated laying a few days before the melt of snow.

\section{Spring temperatures and food for laying birds}

If, similar to other birds in highly seasonal environments (Immelmann 1971; Murton and Westwood 1977; Lambrechts et al. 1996), the breeding time of woodpeckers was under strong photoperiodic control, the increasing day length would be the first cue in preparations for breeding (Pasinelli 2001). However, the short days could affect only the earliest possible laying dates and they could not be responsible for much later breeding in most years. Too low temperatures in the pre-breeding period might be the main arresting factor.

Higher temperatures could affect the birds' physiology directly. At higher temperatures, they might divert energy and resources saved from maintenance to building up body condition necessary for reproduction. This could be the case in the earliest breeding WB, Hogstad and Stenberg (1997) showed that the energy reserves of WB females in Norway influenced their survival and onset of laying with females in poor condition commenced laying later and laid smaller clutches. It is less probable that savings of energy on body maintenance per se could be important in setting laying dates in the later breeding species. Higher temperatures could affect them indirectly, e.g. by speeding up the development of invertebrate food (see below), or they could serve as a cue helping the birds to predict future conditions (Nilsson 1994; Svensson and Nilsson 1995; Wesołowski and Rowiński 2014).

However, even if temperature influenced the birds directly, their thresholds of acceptance were not fixed. Much lower daily temperatures were sufficient to induce the woodpeckers to breed early than late in the spring (Fig. 5). The longer days later in the season allow more time for foraging, which could offset the lower temperatures to some extent (Perrins and McCleery 1989). This suggests that temperature has to be weighted (calibrated) against day length to trigger the breeding (Wesołowski 1998; Lambrechts and Perret 2000; Gienapp et al. 2005).

Perrins $(1965,1970)$ proposed that females attempted to breed as early as possible, but their laying was, in many cases, arrested by inability to get enough food to build up body resources necessary for reproduction. Therefore, the availability of food for the egg-forming birds would be most critical in shaping variation in breeding times and it is, therefore, crucial to know which food types the females rely upon in the pre-breeding and egg-laying periods. Higher temperatures could affect food resources in several ways, by making new feeding substrates accessible (snow melting, see above), 
by speeding up the development of invertebrates and/or by making active invertebrates easier to detect.

There are several lines of evidence indicating that, within a season, the females indeed attempted to breed as soon as possible. All the species were single-brooded and laid eggs very synchronously (Fig. 2, Table 4). Other studies have shown that clutch size and productivity of broods declined very fast with the relative laying dates (WB-Hogstad and Stenberg 1997, GS—Smith and Smith 2019, LS-Wiktander et al. 2001, Rossmanith et al. 2007, TT-Fayt 2006, Pechacek 2006). That later broods were less productive was also found in MS (Kosiński and Ksit 2006; Mazgajski 2002a) and GS (Hennes 2017). An experiment with food provisioning of GS in the pre-breeding period in England (Smith and Smith 2013), resulted in 4-5 days advancement of laying by those birds provided with supplementary food. Taken together, these observations indicate that there is a strong premium for breeding as early as possible (Daan et al. 1988; Wesołowski 2002; Dunn and Winkler 2010) and the actual laying dates could be constrained by females' ability to gather enough food.

There are only scanty observations on foraging patterns of woodpeckers in Białowieża NP in the pre-breeding period, and no quantitative observations on food types used then; therefore- to reconstruct food sources on which the birds relied then-we use mostly literature data. However, as these observations were made in different geographic areas with non-identical environmental conditions, they must be treated with caution, only as tentative proposals, in need to be confirmed in the future studies. The sources of food on which females of different species rely to get into the reproductive condition differ apparently widely.

WB seems to depend on the same types of food as used in other parts of the year-wood-boring larvae with long residence times in decomposing wood (Glutz von Blotzheim and Bauer 1994; Wiktander et al. 1994; Czeszczewik 2009). Though the supply of this type of larvae is relatively stable throughout the year, their availability tended to increase early in the spring. The disappearance of snow made a fresh supply of logs on the forest floor available for woodpeckers and the birds in Białowieża NP switched to forage on them (Czeszczewik 2009). Additionally, the wood-boring larvae which had become active after termination of diapause were probably easier to detect (Mankin et al. 2011).

Independent of season, MS feeds on surface-living arthropods collected from bark in crowns and on trunks of mostly living trees (Jenni 1983, Pettersson 1983, reviewed in Pasinelli 2003). It switches to folivorous caterpillars while feeding nestlings (see below), but this type of food appears too late in Białowieża NP (Fig. 6) to be used at the egg-forming stage. Two additional sources of food became available in the pre-breeding stage, though. Disappearance of snow and ice from trunks and limbs allowed the birds to use new foraging areas, not exploited in wintertime. Pettersson (1983) observed that early in the spring MS in Sweden foraged mainly on low stem parts of oaks, which were the earliest to become free of snow. The appearance of tree sap leaks on deciduous trees offered second source of food in early spring. It becomes available in Białowieża NP over a month ahead of bud burst (own unpubl. observations) and so it could be used at the egg-formation stage. Tree sap is extensively used by MS at that period. The birds can spend $25 \%$ (Switzerland, Jenni 1983) or even 35\% of foraging time (Sweden, Pettersson 1983) at sap wells then (more refs in Pasinelli 2003). Sap constitutes probably mostly an energy source (though Dengler (2012) dismisses this possibility). Unfortunately, no study quantifying importance of sap for the birds' energy budget is available.

In most of its range, GS is largely a seed eater in winter, and over large parts of Europe, it relies on seeds removed from cones placed in anvils (Osiejuk 1994, Kędra and Mazgajski 2001, refs in Michalek and Miettinen 2003), i.e., on the food resource which is constantly depleted. It is unknown when they switch to invertebrate food and whether they still depend on conifer seeds at the egg-forming stage. Similarly to MS (see above), they breed too early to use folivorous caterpillars in the Białowieża NP, but they can use both areas freed from snow as soon as they become available, as well as tree sap (own unpubl. observations). GS are well known to ring trees with numerous sap wells early in the spring, and may spend $20-30 \%$ of their foraging time at these places at that time (Osmolovskaya 1946, refs in Glutz von Blotzheim and Bauer 1994).

LS foraged in Sweden in the non-breeding season on larvae of several cerambycids living in thin dead branches of living trees, with 1 or 2 year larval development and-in most species-pupating in April-May (Olsson 1998 and refs therein). In the years in which birches or alders blossomed (usually end of March-early April), LS also used short-term flush of Argyresthia goedarthella moth caterpillars emerging from the male catkins of these trees. The birds could use invertebrates from developing leaves, as their laying was well synchronized with oak bud burst (Wiktander et al. 2001), but females still relied mostly on wood living larvae, they spent $82 \%$ of time searching for this type of prey (Wiktander et al. 1994). Females in areas containing higher densities of such larvae commenced breeding earlier (Olsson et al. 1999). The brief 'flushes' of Argyresthia, on the other hand, influenced the relative dates of laying commencement only provided that they occurred several weeks prior to laying (Olsson 1998). In England, on the other hand, surface-living prey appeared to be more important in the pre-breeding period; LS mostly gleaned food from thin living branches of oaks (Charman et al. 2012). In Białowieża NP, the birds bred late enough to take advantage of invertebrates appearing on developing leaves (Fig. 6), but as there 
are no data on LS foraging behaviour, it is impossible to tell whether they used them to a substantial extent.

TT feed mostly on bark beetles (Scolytinae) and other invertebrates living under bark of dying/dead spruces outside the breeding season (Glutz von Blotzheim and Bauer 1994), but they switch to wood-boring cerambycid larvae when feeding their young (Pechacek and Krištín 2004; Fayt 2006 and references therein). It is unknown, though, when this switch occurs, whether the birds use the cerambycid larvae already in the pre-laying period or not. Fayt (2003) suggested that they did and proposed that slow development of these larvae could force females to postpone laying in cold springs. Additionally, TT rings trees in spring (review in Glutz von Blotzheim and Bauer 1994; Pakkala et al. 2017, own unpubl observations in Białowieża NP) and they gain access to tree sap, an additional source of high-energy food at about the egg-laying time.

Summing up, the 'food for females' hypothesis (Perrins 1970) wherein females commence laying at the soonest date they could attain the sufficient condition for reproduction seems to be consistent with the available data on the five woodpecker species. However, scanty information on types of food actually utilized by females in the egg-formation period and almost complete lack of information on dynamics of these food types precludes mechanistic explanation of year-to-year variation of laying times.

There are two other-non-food-factors, which could also delay onset of breeding, namely inability to excavate holes on time and interference with Starlings.

\section{Excavation of holes}

As females need a completed hole to deposit eggs, the laying could be delayed if the hole had not been ready on time. If eggs are laid prematurely to unfinished holes, they are usually removed and the birds continue excavation (MS-Kossenko and Kaygorodova 2003). Since woodpeckers in the Białowieża NP bred in newly excavated holes as a rule (GS and MS—Hebda et al. 2016, 2017), too late completion of excavation could delay egg laying. However, as excavation of a hole could be accomplished in only 8-9 days in GS and MS, or even in 5-6 days in late LS nesting attempts (reviews in Glutz von Blotzheim and Bauer 1994; Pasinelli 2003; Michalek and Miettinen 2003) or, if pressed by time, the birds could reuse an old hole, such delays would probably not substantially constrain laying dates at a population level.

By taking over holes (e.g., Ivanchev 1996; Kosiński and Ksit 2006) and forcing woodpeckers to excavate new ones, Starlings can delay breeding of the woodpeckers (GS in England, Smith 2006). These effects could be only local as in Białowieża NP Starlings co-occur with woodpeckers only at forest edges, i.e., vast majority of woodpeckers have no contact with Starlings. Even if present, Starlings are not always detrimental. They did not usurp holes freshly excavated by GS in an urban park (Mazgajski 2000) and they did not arrest GS or MS egg-laying in the parts of Białowieża NP inhabited by them. This could be partially due to a large excess of available holes, including woodpecker holes from the previous years (see above) or a low density of Starlings. Freshly excavated GS and MS holes appeared too late in a season, to be attractive to Starlings unless there were still excess Starlings seeking a nest hole. On the other hand, the new holes of the earliest breeding WB (Fig. 1) became available on time to be used by the prospecting Starlings and could be taken over by them (Wesołowski 1995). The usurpation of holes was infrequently observed in the study plots (T. Wesołowski, P. Rowiński, unpublished data). This factor could be responsible for a 3-4 day delay of the median dates of egg-laying commencement by this species in adjoining forest edges fragments shared with the Starlings in the Białowieża NP.

\section{Food for young and matching food peak}

To test the Lack's (1950) 'food for young' hypothesis, we must know which food types constitute crucial components of nestling food in a studied species (Immelman 1971, Newton 1998, Durant et al. 2005, review in Cholewa and Wesołowski 2011), to find out whether matching peak of their accessibility is critical for successful reproduction (Cushing 1990; Nilsson 1999; Durant et al. 2005; Cholewa and Wesołowski 2011; Bijlsma 2013).

There are only very limited data on the nestling diet of woodpeckers in the Białowieża Forest. Jenni (1979) recorded foraging sites and food brought to young by a few pairs in spring of 1978. MS, GS, and LS brought mostly surfaceliving invertebrates collected from bark and leaves, the foliophagous caterpillars constituted, respectively, 65, 31, and $98 \%$, of the prey brought by them to the young. TT, on the other hand, collected food largely from dying spruces (92\%) and fed their young mostly with 'whitish' (Cerambycidae?) larvae from under bark. Data on nestling food from other areas are rather scanty as well. They are based on short-term observations of small number (1-31) of broods, often collected several decades ago (Electronic Supplementary Material Table S5), so their generality is doubtful. With so scanty data, it is possible to characterize the nestling diet of different woodpecker species only in a very coarse fashion (we need clearly to fill this knowledge gap, with new quantitative data). WB appears to feed young mostly with wood-boring (mainly Cerambycidae) larvae, folivorous caterpillars can gain importance only occasionally (Electronic Supplementary Material Table S5). In Białowieża NP, they collected food mainly from partially decomposed logs and snags of deciduous trees (Czeszczewik 2009). The nestling food of TT contains large proportion of wood-boring (presumably 
chiefly Cerambycidae) larvae in all the studies (Electronic Supplementary Material Table S5), supplemented by spiders/winged insects. TT hardly feed their young with bark beetle larvae (Fayt 2003, Pechacek and Krištín 2004), but collects food chiefly from dying/dead spruces, mostly hidden under the bark or only shallowly buried (Pechacek and Krištín 1996; Fayt 2006).

The three other species bring mostly surface-living invertebrates collected from bark and leaves to the nestlings (Electronic Supplementary Material Table S5). GS is the most versatile species, using various mixtures of invertebrates in different areas, including low proportion (usually below 50\%, Electronic Supplementary Material Table S5) of folivorous caterpillars. MS and LS use the caterpillars to a largest extent, more than half of their nestlings' food consists of this prey type (Electronic Supplementary Material Table S5). Therefore, 'mis-match' between the folivorous caterpillars' availability and nestlings' requirements could be important only for the latter two species, perhaps to some extent for GS, whereas temporal match between presence of nestlings and availability of wood-boring larvae in deciduous logs or in dying spruces could be relevant in WB and TT, respectively.

\section{Caterpillars' peak}

Each year, independently of overall supply of folivorous caterpillars in that season, the amount of frassfall in Białowieża NP increased from the caterpillars' emergence to a single seasonal peak and declined thereafter. It took from 21 to 40 days from the caterpillars' emergence to seasonal peak of frassfall (Wesołowski et al. 2019). Due to enormous variability in the numbers of caterpillars (more than 100fold variation of frass peak across years, Wesołowski and Neubauer 2017), their supply could be strikingly different. Birds feeding young at the peak date in 'low caterpillars' years could have fewer of them than the birds mismatching the peak by a wide margin in the years in which they were superabundant during long periods of time (Smith and Smith 2019; Wesołowski et al. 2019).

Broods of GS and MS in Białowieża NP were often relatively well matched with the caterpillar peak. In most seasons, the young from the earliest commenced clutches were half-grown at the caterpillar peak (c.12-13 days old, Fig. 7), whereas young from the medially commenced clutches were 3 (GS) to 7 (MS) days old then. The brood rearing time of these two species largely overlapped the period of the caterpillar presence in tree crowns, but most of it fell to the fast-declining phase of their availability (cf. Wesołowski and Neubauer 2017). The coupling between young rearing periods and timing of caterpillar presence was not very close; in some years, none of clutches hatched before the peak, while the young were almost about to fledge in the others (Fig. 7).
A parallel study in England showed that also there is the GS nestling period coincided with the time of caterpillars presence, the median age of nestlings in the earliest broods at the caterpillar peak date amounted to 19 days (a week more than in Białowieża NP), and that the nestling age at the peak varied widely among the springs, from just hatched to almost ready to fledge. Nest success was not related to caterpillars' abundance or synchrony, but the number of fledglings increased when broods were well synchronized and caterpillars' abundance was high (Smith and Smith 2019).

It seems, however, that it is the early nestling period, rather than the period of maximum food demand, which is critical for successful nesting in GS and MS. When prolonged rain spells happened while there were naked, still unable to thermoregulate, young in holes, there was increased nestling mortality, both in MS (Pasinelli 2001; Kosiński and Ksit 2006) and GS (Mazgajski 2002b; Ivanchev 2004; Kosiński and Ksit 2006; Hennes 2017). Therefore, the birds would profit from matching their early nestling period with the caterpillar peak. This was generally the case; the nestlings in the earliest MS and GS broods in Białowieża NP were most often about 10-12 days old at the caterpillar peak (Fig. 7); therefore, young in the broods hatched at median dates were c. 3-7 days old then.

The results for GS and MS are largely consistent with the 'food for young' matching hypothesis, the idea that birds timed their reproduction so as to synchronize their brood rearing time with the highest caterpillar supply. However, large variation in synchrony among years casts some doubt on this claim and prompts one to wonder whether it is really a cause-effect relationship or just coincidence. For example, in the Nuthatch (Wesołowski et al. 2019), the birds started to lay as early as they could and opportunistically fed young with whatever food type was most profitable when it came to the chick rearing time. Unfortunately, we do not have precise data on relationship between the variation in the caterpillars' supply and the woodpeckers foraging behaviour, to check this idea in detail.

Though LS depends most on folivorous caterpillars for nestling food (Electronic Supplementary Material Table S5), its nestling period did not match the caterpillar peak; LS eggs began to hatch in Białowieża NP only around the peak date (Fig. 7) and the nestlings were present when caterpillars in tree crowns were already fast disappearing (Wesołowski and Neubauer 2017). This probably forced them to feed older young, especially in later broods, with other items, e.g., with aphids, as it was the case in Germany (Rossmanith et al. 2007). Partial losses and total brood failures of LS occurred mostly at the early nestling stages, when parents had to brood their naked nestlings in poorly insulated holes almost constantly and had reduced time available for foraging and collecting food for nestlings. This was even more critical when brood was tended by a single parent (frequent 
condition due to polyandry, Wiktander et al. 2000). Wiktander et al. $(1994,2001)$ and Rossmanith et al. (2007) suggested, therefore, that availability of caterpillars was crucial just at this stage of nesting. They proposed that the LS reproduction was timed to make the brooding period, and not the period of the maximum energy demand of nestlings, coincide with the time of highest caterpillar availability. This could account for such a late onset of laying in this species. An additional, perhaps relevant in this context, advantage of late breeding, is that young appeared when ambient temperatures are on average higher than early in the spring.

Two species, WB and TT, rely on wood-boring insects to feed their young (see above). Such prey becomes most profitable when fully grown (last instar larvae, pupae) and when insects become accessible close to the surface (under bark, in phloem)—Matsuoka (1979), Wiktander et al. (1994), Fayt (2006). Such conditions occur during short period close to the emergence time of the insects. Therefore, these periods would set the food peak period with which these the birds should attempt to synchronize.

The availability of wood-boring larvae in the Białowieża Forest was highest early in the season as imagoes of several species of Cerambycidae had already emerged in June (Gutowski 1988). This could explain the early breeding of WB. Matsuoka (1979) argued that WB, the largest species, was too heavy to use folivorous caterpillars in tree crowns effectively and, hence, it had to stick to wood-inhabiting larvae from decomposing wood, as a source of its nestling food. The availability of such insects declines with the season (due to emergence of imagos or to larvae burrowing deeper); they are forced to breed early. Our observations are consistent with this explanation; WB in Białowieża NP bred very early and gathered most of their food from dead, partially softened trunks and logs of deciduous trees, by gleaning, scaling and shallow pecking (Czeszczewik 2009).

Though TT also relied on larvae of the wood-boring insects, it was the latest breeding woodpecker in Białowieża NP commencing laying a month later than WB (Fig. 1). The contrast could be related to the different patterns of insect development in deciduous trees used by foraging WB and in spruces used by TT. Though imagoes of several spruce living long-horn beetles had already started to emerge in May (Gutowski 1988), when most TT had only commenced egg laying, but peak of emergence of Tetropium sp. (found in nestling food collection, Jenni 1979) and of Rhagium spp. (the beetle, which larvae constituted a bulk of nestling food in the Alps, Pechacek and Krištín 1993, 1996) occurred in Białowieża NP in the first and second decades of June (Gutowski 1988), i.e., at the time of rearing young there. After finding that the number of dispersing TT juveniles in Finland was especially low in years with exceptionally warm springs, Fayt (2006) suggested that the larvae developed too fast then and the birds were unable to adjust their clutch initiation dates to match their young rearing time with the development time of the long-horn beetles.

To summarise, the data on relationships between timing of laying and availability of nestling food show that the woodpeckers nest, so that, in broad terms, their young rearing time coincides with abundance of appropriate food for their nestlings. There is not much evidence, demonstrating that the birds fine-tune (match) their breeding to the seasonal peaks in food availability (as measured by frass collection). Perhaps, it is to be expected, as fine tuning of breeding to the food peaks is important only when nestling food supply remains inadequate except for the brief period around the peak (Dunn and Winkler 2010). However, if periods with a more than adequate amount of food last longer, or if they have broad plateaus of abundance rather than sharp peaks, as it often happens in Białowieża NP (Wesołowski and Rowiński 2006; Maziarz and Wesołowski 2010; Wesołowski and Neubauer 2017; Wesołowski et al. 2019), then there is little selective advantage of perfect matching.

\section{Long-term trends and climate warming}

All the studied woodpecker species advanced egg-laying in Białowieża NP over 45 years, yet not at the same rates. The earliest breeding WB accelerated least and the late nesting TT the most. In consequence, TT started to begin c. 37 days after WB in 1975-1984 but only c. 28 days following it in 2014-2019. In all species but the earliest initiating WB, these phenological shifts could be related to warming of the second half of April (up to c. 2000, with no further rise thereafter, Fig. 4), while all the species could respond to a strong long-term advance (40 days, Fig. 4) in disappearance of snow cover. The inter-specific sequence of laying has been retained and the early laying dates observed recently remained within the range of earlier recorded ones, the early springs just became more frequent.

Similar long-term trends to breed earlier were observed in GS in other areas. It advanced breeding in other parts of Poland (5 days/24 years; 1980-2003, Polish Nest Record Scheme, Hebda and Szewczyk 2005), in West Germany (7 days/12 years, Hennes 2018), and in England (20 days/33 years Smith and Smith 2019,). In the latter country, the advancement was initially (1990-1999) faster -0.4 days/year and slower -0.2 days/years - later on (2000-2016, Smith and Smith 2019).

The studied woodpeckers followed the general response observed in birds with an advance of laying dates with increasing spring temperatures (review in Dunn and Winkler 2010). The existence of these shifts have raised numerous concerns as to their possible negative effects on the reproduction of birds. It has been argued that the (presumably) co-adapted phenology of trees, folivorous caterpillars, and their avian predators could be disrupted 
by mismatches at numerous levels in the food chain. Any mismatch could in turn, via changes in the nourishment of young, result in lowered reproductive success and a lower survival rate of young. Such proposals are frequently made (review in Visser et al. 2012), but information on the actual composition of the nestling diet (Dunn and Winkler 2010; Cholewa and Wesołowski 2011) or food availability is only infrequently provided. Because of the paucity of data, our understanding of effects of temperature on the food supply and breeding performance of birds is still unsatisfactory. The woodpeckers (see above) make no exception in this respect. Therefore, carrying out studies directed at understanding the mechanistic relationships between weather, food supply and avian breeding performance, as well as the physiological basis for these relationships, should be strongly encouraged. Such studies are necessary for linking the responses of birds to general models of climate and predicting long-term changes in populations (Dunn and Winkler 2010).

Changes in the local climate caused by global warming in the Białowieża Forest remain so far within the range of climatic variation, that ancestors of local organisms have experienced before. The higher temperatures observed recently are still within the range of variability recorded in Białowieża Forest in historical times (Jędrzejewska and Jędrzejewski 1997; Wesołowski and Cholewa 2009). Also phenological shifts observed among woodpeckers of Białowieża NP are thus far within the range of variability faced by these populations in the past (see above). The current challenges are neither novel nor unique, and it seems that, in terms of the timing of their breeding, the birds can cope with them adequately by plastic behavioural and physiological adjustments (Wesołowski and Cholewa 2009). However, as warming trends are predicted to continue, sometime in the future, the changes could reach a point beyond which the ability of local organisms to deal with them would be exceeded, and large disruption of trophic links could ensue. The most precarious is fate of TT. This woodpecker is so strongly dependent on the presence of dying spruces (see above), that forecast climate-driven disappearance of this tree species from the Białowieża Forest (Dyderski et al. 2018) could result in local extinction of this woodpecker.

Acknowledgements We are very grateful to D. Czeszczewik, C. Mitrus, M. Maziarz, M. Czuchra, and L. Tomiałojć for help in nest finding. We thank the Białowieża National Park administration for their kind co-operation. Preparation of this paper was supported by internal grants from the Faculty of Biological Sciences, Wrocław University (TW), and Institute of Biology, Opole University (GH). We thank G. Pasinelli, S. M. Kossenko, and K. W. Smith for help with literature queries, and K.W. Smith for data sharing, linguistic help, and useful comments on the early draft of this paper. We are also grateful to two anonymous referees for constructive comments on the earlier versions of this paper.
Open Access This article is licensed under a Creative Commons Attribution 4.0 International License, which permits use, sharing, adaptation, distribution and reproduction in any medium or format, as long as you give appropriate credit to the original author(s) and the source, provide a link to the Creative Commons licence, and indicate if changes were made. The images or other third party material in this article are included in the article's Creative Commons licence, unless indicated otherwise in a credit line to the material. If material is not included in the article's Creative Commons licence and your intended use is not permitted by statutory regulation or exceeds the permitted use, you will need to obtain permission directly from the copyright holder. To view a copy of this licence, visit http://creativecommons.org/licenses/by/4.0/.

\section{References}

Aulén G (1988) Ecology and distribution history of the WhiteBacked Woodpecker Dendrocopos leucotos in Sweden. Swedish University of Agricultural Sciences, Department of Wildlife Ecology. Report 14:1-253

Bairlein F, Winkel W (2000) Birds and climate change. In: Lozan JL, Grassl H, Hupfer P (eds) Climate of the 21st century. Changes and risks. Wissenschaftliche Auswertungen, Hamburg

Bijlsma RG (2013) Ornithology from the tree tops. Ardea 101:85-86

Bobiec A (2002) Living stands and dead wood in the Białowieża Forest: suggestions for restoration management. Forest Ecol Manag 165:125-140

Burgess MD, Smith KW, Evans KL, Leech D, Pearce-Higgins JW, Branston CJ, Briggs C, Clark JR, du Feu ChR, Lewthwaite K, Nager RG, Sheldon BC, Smith JA, Whytock RC, Willis SG, Philliomore AB (2018) Tritrophic phenological match-mismatch in space and time. Nat Ecol Evol 2:970-975

Charman EC, Smith KW, Dillon IA, Dodd S, Gruar DJ, Dillon IA (2012) Pre-breeding foraging and nest site habitat selection by Lesser Spotted Woodpeckers Dendrocopos minor in mature woodland blocks in England. Orn Fenn 89:182-196

Charmantier A, Gienapp P (2014) Climate change and timing of avian breeding and migration: evolutionary versus plastic changes. Evol Appl 7:15-28

Chmielewski FM, Rötzer T (2001) Response of tree phenology to climate change across Europe. Agr Forest Meteorol 108:101-112

Cholewa M, Wesołowski T (2011) Nestling food of European holenesting passerines: do we know enough to test the adaptive hypotheses on breeding seasons? Acta Orn 46:105-116

Cisakowski R (1992) Methods for estimating the stage in the nesting cycle for woodpeckers (Picinae). Not Orn 33:303-311 (in Polish, English summary)

Crick QP, Sparks TH (2006) Changes in the phenology of breeding and migration in relation to global climate change. Acta Zool Sin Suppl 52:154-157

Cushing DH (1990) Plankton production and year-class-strength in fish populations - an update of the match mismatch hypothesis. Adv Mar Biol 26:249-293

Czeszczewik D (2009) Foraging behaviour of White-backed Woodpeckers Dendrocopos leucotos in a primeval forest (Białowieża National Park, NE Poland): dependence on habitat resources and season. Acta Orn 44:109-118

Daan S, Dijkstra C, Drent R, Meijer T (1988) Food supply and the annual timing of avian reproduction. Acta XIX Congr Intern Orn 1:392-407

Dajoz R (ed) (2000) Insects and forests. Intercept Ltd., Paris

Dengler K (2012) Thesen und Fakten rund um die Spechtringelung. Schriftenreihe der Hochschule für Forstwirtschaft Rottenburg am Neckar 23:1-600 
Drake A, Martin K (2018) Local temperatures predict breeding phenology but do not result in breeding synchrony among a community of resident cavity-nesting birds. Sci Rep 8:2756

Drent RH (2006) The timing of birds' breeding seasons: the Perrins hypothesis revisited especially for migrants. Ardea 94:305-322

Dunn PO, Winkler DW (2010) Effects of climate change on timing of breeding and reproductive success in birds. In: Møller AP, Fiedler W, Berthold P (eds) Effects of climate change on birds. Oxford University Press, Oxford

Durant JM, Hjermann DØ, Anker-Nilssen T, Beaugrand G, Mysterud A, Pettorelli N, Stenseth NC (2005) Timing and abundance as key mechanisms affecting trophic interactions in variable environments. Ecol Lett 8:952-958

Dyderski MK, Paź S, Frelich LE, Jagodziński AM (2018) How much does climate change threaten European forest tree species distributions? Global Change Biol 24:1150-1163

Fayt P (2003) Time of natal dispersal and reproductive decisions of the Three-toed Woopecker under varying food condition. Nationalparkverwaltung Berchtesgaden Forschungsbericht 48:35-48

Fayt P (2006) Reproductive decisions of boreal three-toed woodpeckers (Picoides tridactylus) in a warming world: from local responses to global population dynamics. Ann Zool Fenn 43:118-130

Gienapp P, Hemerik L, Visser ME (2005) A new statistical tool to predict phenology under climate change scenarios. Glob Change Biol 11:600-606

Glue DE, Boswell T (1994) Comparative nesting ecology of the three British breeding woodpeckers. Brit Birds 87:253-269

Glutz von Blotzheim UN, Bauer K (1994) Handbuch der Vögel Mitteleuropas, vol 9. Akademische Verlagsgeselschaft, Wiesbaden

Gutowski JM (1988) Phenology of Cerambycidae (Coleoptera) in the Białowieża Primeval Forest. Folia Forest Polon A 29:93-104 (in Polish, English summary)

Gutowski JM, Jaroszewicz B (2016). Zmiany udziału świerka pospolitego w drzewostanach Puszczy Białowieskiej w kontekście dynamiki liczebności kornika drukarza Ips typographus (L.). In: Stan ekosytemów leśnych Puszczy Białowieskiej. Centrum Informacyjne Lasów Państwowych, Warszawa (in Polish)

Hebda G, Szewczyk M (2005) Breeding season, clutch size and reproductive success of the Great Spotted Woodpecker Dendrocopos major in Poland - an analysis of nest cards. Not Orn 46:133-141 (in Polish, English summary)

Hebda G, Wesołowski T, Rowiński P (2016) Nest sites of Middle Spotted Woodpeckers Leiopicus medius in a primeval forest. Ardea 104:119-128

Hebda G, Wesołowski T, Rowiński P (2017) Nest sites of a strong excavator, the Great Spotted Woodpecker Dendrocopos major, in the Białowieża National Park (Poland). Ardea 105:61-71

Hennes R (2017) Poulationsdynamik einer fakultativ polyandrischen Population des Buntspechtes Dendrocopos major. Charadrius 53:48-50

Hennes R (2018) Zur Populationsbiologie des Buntspechtes - Der Einfuss der Witterung auf Brutbeginn und -erflog. Ornithol Anz 57:73-75

Hogstad O, Stenberg I (1997) Breeding success, nestling diet and parental care in the White-Backed Woodpecker Dendrocopos leucotos. J Orn 138:25-38

Hogstad O, Stenberg I (2005) Sexual differences in physical condition in the White-backed Woodpecker Dendrocopos leucotos in relation to habitat type and across seasons. Orn Fenn 82:26-31

Immelmann K (1971) Ecological aspects of periodic reproduction. In: Farner DS, King JR (eds) Avian biology. Academic Press, New York

IPCC (2014) Climate Change 2014: Synthesis Report. Contribution of Working Groups I, II and III to the Fifth Assessment Report of the Intergovernmental Panel on Climate Change [Core Writing Team, Pachauri RK, Meyer LA (eds.)]. IPCC, Geneva, Switzerland

Ivanchev VP (1995) Biologija gnezdovanija malogo pestrogo djatla v Okskom Zapovednike. Trudy Okskogo Biosfernogo Gosudarstvennogo Zapovednika 19:140-158 (in Russian)

Ivanchev VP (1996) Distribution, numbers and ecology of the whitebacked woodpecker Dendrocopos leucotos in European part of Russia. Russian Journal of Ornithology 5:117-128 (in Russian, English summary)

Ivanchev VP (2004) The biology of the Great Spotted Woodpecker Dendrocopos major in the Oka Reserve. Proceedings Oka Reserve 23:9-56 (in Russian, English summary)

Jenni L (1979) Oekologische und Morphologische Unterschiede Zwischen Buntspecht und Mittelspecht (Dendrocopos major pinetorum und D. medius). Diplomarbeit, Basel University

Jenni L (1983) Habitatnutzung, Nahrungserwerb und Nahrung von Mittel- und Buntspecht (Dendrocopos medius und D. major) sowie Bemerkungen zur Verbreitungsgeschichte des Mittelspechtes. Orn Beob 80:29-57

Jędrzejewska B, Jędrzejewski W (1997) Predation in vertebrate communities. Springer, Berlin

Kędra AH, Mazgajski TD (2001) Factors affecting anvils utilization by Great Spotted Woodpecker Dendrocopos major. Pol J Ecol 49:79-86

Kosiński Z, Ksit P (2006) Comparative reproductive biology of Middle Spotted Woodpeckers Dendrocopos medius and Great Spotted Woodpeckers D. major in a riverine forest. Bird Study 53:237-246

Kossenko SM, Kaygorodova EYu (2003) Ecological features of the Middle Spotted Woodpecker (Dendrocopos medius) in the Desna Polesie. Ornithologia 30:94-103 (in Russian, English summary)

Kossenko SM, Kaygorodova EYu (2007) Reproduction of the Middle Spotted Woodpecker Dendrocopos medius in the NerussaDesna woodland, SW Russia, with particular reference to habitat fragmentation, weather conditions and food supply. Ardea 95:177-189

Lack D (1950) The breeding seasons of European birds. Ibis 92:288-316

Lambrechts MM, Perret P (2000) A long photoperiod overrides nonphotoperiodic factors in Blue Tits' timing of reproduction. Proc R Soc Lond B 267:585-588

Lambrechts MM, Perret P, Blondel J (1996) Adaptive differences in the timing of egg laying between different populations of birds result from variation in photoresponsiveness. Proc R Soc Lond B 263:19-22

Mankin RW, Hagstrum DW, Smith MT, Roda AL, Kairo MTK (2011) Perspective and promise: a century of insect acoustic detection and monitoring. Am Entomol 57:3-44

Matsuoka S (1979) Ecological significance of the early breeding in White-backed Woodpeckers Dendrocopos leucotos. Tori 2:63-75

Mazgajski TD (2000) Competition for nest sites between the Starling Sturnus vulgaris and other cavity nesters - study in forest park. Acta Orn 35:103-107

Mazgajski TD (2002a) Nesting interaction between woodpeckers and starlings - delayed commensalism, competition for nest sites or cavity kleptoparasitism? In: Pechacek P, d'Oleire-Oltmanns International Woodpecker Symposium. Nationalparkverwaltung Berchtesgaden Forschungsbericht 48:133-138

Mazgajski TD (2002b) Nesting phenology and breeding success in Great Spotted Woodpecker Picoides major near Warsaw (Central Poland). Acta Orn 37:1-5

Maziarz M, Wesołowski T (2010) Timing of breeding and nestling diet of Wood Warbler Phylloscopus sibilatrix in relation to changing food supply. Bird Study 57:540-552 
Michalek K, Miettinen J (2003) Dendrocopos major Great Spotted Woodpecker. BWP Update 5:101-184

Mitrus C, Soćko B, Dołegowska M, Zozula P (2005) The breeding phenology of Red-breasted Flycatcher Ficedula parva in Białowieża Forest. Not Orn 46:213-219 (in Polish, English summary)

Murton RK, Westwood NJ (1977) Avian breeding cycles. Clarendon Press, Oxford

Naef-Daenzer B, Widmer F, Nuber M (2001) Differential post-fledging survival of great and coal tits in relation to their condition and fledging date. J Anim Ecol 70:730-738

Newton I (1998) Population limitation in birds. Academic Press, London

Niechoda T, Korbel J (2011) Puszczańskie olbrzymy. Towarzystwo Ochrony Krajobrazu, Białowieża (in Polish)

Niemelä J (1997) Invertebrates and boreal forest management. Conserv Biol 11:601-610

Nilsson JÅ (1994) Energetic bottle-necks during breeding and the reproductive cost of being too early. J Anim Ecol 63:200-208

Nilsson JÅ (1999) Fitness consequences of timing of reproduction. In: Adams NJ, Slotow RH (eds) Proc 22 Int Ornithol Congr, Durban, Bird Life South Africa, Johannesburg

Nilsson JÅ, Smith HG (1988) Effects of dispersal date on winter flock establishment and social dominance in marsh tit Parus palustris. J Anim Ecol 57:17-928

Olsson O (1998) Through the eyes of a woodpecker: understanding habitat selection, territory quality and reproductive decisions from individual behaviour. $\mathrm{PhD}$ thesis, Lund University

Olsson O, Wiktander U, Holmgren NMA, Nilsson SG (1999) Gaining ecological information about Bayesian foragers through their behaviour. II A field test with woodpeckers. Oikos 87:264-276

Osiejuk TS (1994) Sexual dimorphism in foraging behaviour of the Great Spotted Woodpecker Dendrocopos major of Scotch pine seeds. Orn Fenn 71:144-150

Pakkala T, Kouki J, Piha M, Tiainen J (2017) Phloem sap in fire-damaged Scots pine trees provides instant foraging opportunities for Three-toed Woodpeckers Picoides tridactylus. Ornis Svecica 27:144-149

Pasinelli G (2001) Breeding performance of the Middle Spotted Woodpecker Dendrocopos medius in relation to weather and territory quality. Ardea 89:353-436

Pasinelli G (2003) Dendrocopos medius Middle Spotted Woodpecker BWP Update 5:49-99

Pavlík Š (1999) Breeding ecology of the white-backed woodpecker Dendrocopos leucotos in an oak forest. Biologia 54:187-194

Pechacek P (2006) Breeding performance, natal dispersal, and nest site fidelity of the three-toed woodpecker in the German Alps. Ann Zool Fenn 43:165-176

Pechacek P, Krištín A (1993) Diet of Woodpeckers, Piciformes in Berchtesgaden National Park. Vogelwelt 114:165-177

Pechacek P, Krištín A (1996) Food and foraging ecology of the Threetoed Woodpecker Picoides tridactylus during the nestling period. Orn Beob 93:259-266

Pechacek P, Kristin A (2004) Comparative diets of adult and young Three-toed Woodpeckers in a European Alpine forest community. J Wildl Manage 68:683-693

Perrins CM (1965) Population fluctuations and clutch-size in the great tit, Parus major L. J Anim Ecol 34:601-647

Perrins CM (1970) The timing of birds' breeding seasons. Ibis 112:242-255

Perrins CM (1973) Some effects of temperature of breeding in the Great Tit and Manx Shearwater. J Reprod Fertil 19:162-173

Perrins CM (1991) Tits and their caterpillar food supply. Ibis 133:49-54

Perrins CM, McCleery RH (1989) Laying dates and clutch size in the Great Tit. Wilson Bull 101:236-253
Pettersson B (1983) Foraging behaviour of the middle spotted woodpecker Dendrocopos medius in Sweden. Holarct Ecol 6:263-269

Pulido F, Berthold P (2004) Microevolutionary response to climatic change. Adv Ecol Res 35:151-183

Rossmanith E, Höntsch K, Blaum N, Jeltsch F (2007) Reproductive success and nestling diet in the Lesser Spotted Woodpecker (Picoides minor): the early bird gets the caterpillar. J Orn 148:323-332

Rowiński P. 2001. Timing of breeding of Nuthatch Sitta europaea in relation to food resources in a natural forest. Unpublished Biol. D. thesis, Agricultural University, Warsaw (in Polish)

Ruffino L, Salo P, Koivisto E, Banks P, Korpimäki E (2014) Reproductive responses of birds to experimental food supplementation: A meta-analysis. Front Zool 2014:1-13. https://doi.org/10.1186/ s12983-014-0080-y

Ruge K (1974) Zur Biologie des Dreizehenspechtes Picoides tridactylus. Orn Beob 71:303-311

Scherzinger W (1982) Die Spechte im Nationalpark Bayerischer Wald. Bayerischen Staatsministerium für Ernährung, Landwirtschaft und Forsten 9:1-119

Schiegg K, Pasinelli G, Walters JR, Daniels SJ (2002) Inbreeding and experience affect response to climate change by endangered woodpeckers. Proc R Soc B 269:1153-1159

Schmidt KH (1984) Spring temperature and time of laying in tits. J Ornithol 125:321-331

Smith KW (2006) The implication of nest site competition from starlings Sturnus vulgaris and the effect of spring temperatures on the timing and breeding performance of great spotted woodpeckers Dendrocopos major in Southern England. Ann Zool Fenn 43:177-185

Smith KW, Smith L (2013) The effect of supplementary feeding in early spring on the breeding performance of the Great Spotted Woodpecker Dendrocopos major. Bird Study 60:169-175

Smith KW, Smith L (2019) Does the abundance and timing of defoliating caterpillars influence the nest survival and productivity of the Great Spotted Woodpecker Dendrocopos major? Bird Study 66:188-197

StatSoft, Inc. (2014) STATISTICA (data analysis software system), version 12. www.statsoft.com

Stutchbury BJM, Morton ES (2001) Behavioral ecology of tropical birds. Academic Press, New York

Svensson E, Nilsson JA (1995) Food supply, territory quality, and reproductive timing in the Blue Tit (Parus caeruleus). Ecology 76:1804-1812

Taczanowski W (1882) Ptaki krajowe, vol 2. Akademia Umiejętności, Kraków (In Polish)

Tomiałojć L, Wesołowski T (1990) Bird communities of the primaeval temperate forest of Białowieża, Poland. In: Keast A, Blondel J, Helle P, Kikkawa J, Recher HW, Holmes RT (eds) Biogeography and ecology of forest bird communities, SPB Academic Publishers, Hague

Tomiałojć L, Wesołowski T (2004) Diversity of the Białowieża Forest avifauna in space and time. J Orn 145:81-92

Tomiałojć L, Wesołowski T (2005) The avifauna of Białowieża Forest: a window into the past. Br Birds 98:174-193

Tomiałojć L, Wesołowski T, Walankiewicz W (1984) Breeding bird community of a primaeval temperate forest (Białowieża National Park, Poland). Acta Orn 20:241-310

Van Dongen S, Backeljau T, Matthysen E, Dhondt AA (1997) Synchronization of hatching date with bud burst of individual host trees (Quercus robur) in the winter moth (Operophtera brumata) and its fitness consequences. J Anim Ecol 66:113-121

Visser ME, Holleman LJM, Gienapp P (2006) Shifts in caterpillar biomass phenology due to climate change and its impact on the breeding biology of an insectivorous bird. Oecologia 147:164-172 
Visser ME, te Marvelde L, Lof ME (2012) Adaptive phenological mismatches of birds and their food in a warming world. J Orn 153:75-84

Visser ME, van Noordwijk AJ, Tinbergen JM, Lessells CM (1998) Warmer springs lead to mistimed reproduction in Great Tits (Parus major). Proc R Soc Lond B 265:1867-1870

Wesołowski T (1995) Ecology and behaviour of White-backed Woodpecker (Dendrocopos leucotos) in a primaeval temperate forest (Białowieża National Park, Poland). Vogelwarte 38:61-75

Wesołowski T (1998) Timing and synchronisation of breeding in a Marsh Tit Parus palustris population from a primaeval forest. Ardea 86:89-100

Wesołowski T (2000) Time saving mechanisms in the reproduction of Marsh Tits Parus palustris. J Orn 141:309-318

Wesołowski T (2002) Antipredator adaptations in nesting Marsh Tits Parus palustris: the role of nest site security. Ibis 144:593-601

Wesołowski T (2005) Virtual conservation: how the European Union is turning a blind eye on its vanishing primeval forests. Conserv Biol 19:1349-1358

Wesołowski T (2007) Primeval conditions - what can we learn from them? Ibis 149(suppl 2):64-77

Wesołowski T, Cholewa M (2009) Climate variation and birds' breeding seasons in a primeval temperate forest. Clim Res 38:199-208

Wesołowski T, Cholewa M, Hebda G, Maziarz M, Rowiński P (2016) Immense plasticity of timing of breeding in a sedentary forest passerine, Poecile palustris. J Avian Biol 47:129-133

Wesołowski T, Czeszczewik D, Hebda G, Maziarz M, Mitrus C, Rowiński P (2015) 40 years of breeding bird community dynamics in a primeval temperate forest (Białowieża National Park, Poland). Acta Orn 50:95-120

Wesołowski T, Czeszczewik D, Mitrus C, Rowiński P (2003) Ptaki Białowieskiego Parku Narodowego. Not Orn 44:1-31 (in Polish, English summary)
Wesołowski T, Neubauer G (2017) Diet of Marsh Tit Poecile palustris nestlings in a primeval forest in relation to food supply and age of young. Acta Orn 52:105-118

Wesołowski T, Rowiński P (2006) Timing of bud burst and tree-leaf development in a multispecies temperate forest. Forest Ecol Manag 237:387-393

Wesołowski T, Rowiński P (2008) Late leaf development in pedunculate oaks Quercus robur L.: an antiherbivore defence? Scand J For Res 23:386-394

Wesołowski T, Rowiński P (2014) Do Blue Tits Cyanistes caeruleus synchronize reproduction with caterpillar peaks in a primeval forest? Bird Study 61:235-245

Wesołowski T, Rowiński P, Neubauer G (2019) Food of Nuthatch Sitta europaea young in a primeval forest: effects of varying food supply and age of nestlings. Acta Orn 54:85-104

Wesołowski T, Tomiałojć L (1986) The breeding ecology of woodpeckers in a temperate primaeval forest-preliminary data. Acta Orn 22:1-22

Wiktander U, Nilsson SG, Olsson O, Stagen A (1994) Breeding success of a Lesser Spotted Woodpecker Dendrocopos minor population. Ibis $136: 318-322$

Wiktander U, Olsson O, Nilsson SG (2000) Parental care and social mating system in the Lesser Spotted Woodpecker Dendrocopos minor. J Avian Biol 31:447-456

Wiktander U, Olsson O, Nilsson SG (2001) Annual and seasonal reproductive trends in the Lesser Spotted Woodpecker Dendrocopos minor. Ibis 143:72-82

Publisher's Note Springer Nature remains neutral with regard to jurisdictional claims in published maps and institutional affiliations. 